Article

\title{
Soil Chemical and Microbiological Properties Are Changed by Long-Term Chemical Fertilizers That Limit Ecosystem Functioning
}

\author{
Yong-Chao Bai ${ }^{1} \mathbb{C}$, Ying-Ying Chang ${ }^{1}$, Muzammil Hussain ${ }^{2} \oplus$, Bin Lu ${ }^{3}$, Jun-Pei Zhang ${ }^{1}$, \\ Xiao-Bo Song ${ }^{1}$, Xia-Shuo Lei ${ }^{1}$ and Dong Pei ${ }^{1, *}$ \\ 1 State Key Laboratory of Tree Genetics and Breeding, Key Laboratory of Tree Breeding and Cultivation of the \\ State Forestry and Grassland Administration, Research Institute of Forestry, Chinese Academy of Forestry, \\ Beijing 100091, China; baiychao@163.com (Y.-C.B.); yingying_chang0123@163.com (Y.-Y.C.); \\ zhangjunpei@caf.ac.cn (J.-P.Z.); xiaobo.song@caf.ac.cn (X.-B.S.); leixiashuo@126.com (X.-S.L.) \\ 2 State Key Laboratory of Mycology, Institute of Microbiology, Chinese Academy of Sciences, \\ Beijing 100101, China; muzammil0991@gmail.com \\ 3 Yunnan Academy of Forestry, Kunming 650000, China; kmlubin@163.com \\ * Correspondence: pei.dong@caf.ac.cn; Tel.: +86-10-62863229
}

Received: 2 April 2020; Accepted: 7 May 2020; Published: 8 May 2020

\begin{abstract}
Although the effects of fertilization and microbiota on plant growth have been widely studied, our understanding of the chemical fertilizers to alter soil chemical and microbiological properties in woody plants is still limited. The aim of the present study is to investigate the impact of long-term application of chemical fertilizers on chemical and microbiological properties of root-associated soils of walnut trees. The results show that soil organic matter $(\mathrm{OM}), \mathrm{pH}_{\mathrm{kcl}}$, total nitrogen $(\mathrm{TN})$, nitrate-nitrogen $\left(\mathrm{NO}_{3}{ }^{-}\right)$, and total phosphorus (TP) contents were significantly higher in non-fertilized soil than after chemical fertilization. The long-term fertilization led to excessive ammonium-nitrogen $\left(\mathrm{NH}_{4}{ }^{+}\right)$and available phosphorus (AP) residues in the cultivated soil, among which $\mathrm{NH}_{4}{ }^{+}$resulted in soil acidification and changes in bacterial community structure, while AP reduced fungal diversity. The naturally grown walnut trees led to an enrichment in beneficial bacteria such as Burkholderia, Nitrospira, Pseudomonas, and Candidatus_Solibacter, as well as fungi, including Trichoderma, Lophiostoma, Phomopsis, Ilyonectria, Purpureocillium, Cylindrocladiella, Hyalorbilia, Chaetomium, and Trichoglossum. The presence of these bacterial and fungal genera that have been associated with nutrient mobilization and plant growth was likely related to the higher soil OM, TN, $\mathrm{NO}_{3}{ }^{-}$, and TP contents in the non-fertilized plots. These findings highlight that reduced chemical fertilizers and organic cultivation with beneficial microbiota could be used to improve economic efficiency and benefit the environment in sustainable agriculture.
\end{abstract}

Keywords: walnut; fertilization; sustainable agriculture; soil chemical properties; microbial communities

\section{Introduction}

The unreasonable use of chemical fertilizers has negatively impacted the environment, caused food security issues, and reduced our dependency on the positive services that soil biodiversity provides for plant performance [1-3]. In conventional agriculture, however, chemical fertilizers are frequently used to obtain higher crop yields, but only $10 \%-40 \%$ of the fertilizers applied can be directly absorbed and used by plants. The remaining fertilizers in the soil are in the form of insoluble inorganic salts or leached into adjacent rivers, which is considered a major threat to global soil biodiversity [4-7]. The soil microbiota plays important roles, such as participating in the biogeochemical cycling of soil nutrients [8-10], helping to withstand abiotic stresses [11,12], producing phytohormones that improve 
plant growth [13], and preventing infections by phytopathogens [14-16]. Similarly, the plants host microbes and release root exudates that serve as a food source for soil microbiota [17]. The use of plant growth-promoting rhizobacteria (PGPR) and fungi (PGPF) may provide a sustainable alternative to the use of chemical fertilizers $[18,19]$.

Walnut (Juglans spp.) is an economically important tree for nut and wood products that is widely grown in many countries. Due to its oil content and quality, walnut is known as the "king of plant oils". Unsaturated fatty acids account for more than $90 \%$ of the total fat content [20]. In recent years, the production and consumption of walnut have substantially increased owing to the high nutritional value based on its fat content. The growers sought to largely increase walnut yields with the consequent overuse of chemical fertilizers. This had consequences for the environment, thereby affecting soil quality and causing diseases like leaf spot, anthracnose, walnut blight, canker, and brown apical necrosis $[4,21,22]$. Altogether, this resulted in economic losses for J. regia L. trees by decreasing the amount and quality of harvested walnut nuts. To improve the planting efficiency of walnut and reduce its negative impact on the environment, organic cultivation of walnut trees with a reduced application of chemical fertilizer and enhanced microbiological function needs to be further developed.

Previous studies have shown that plants that rarely have root hairs can promote the uptake of nutrients by establishing mutualism with soil microorganisms [23,24]. We hypothesize that the microbiota in natural ecosystems impacts nutrient uptake in trees and cycling of soil nutrients, but due to the lack of root hairs in walnut, a large number of chemical fertilizers in the cultivated orchard destroy the soil microbial community and soil quality, resulting in the weak nutrient absorption capacity of trees and lower soil fertility $[19,25,26]$. However, to our knowledge, few studies have reported on the ecological effects of long-term fertilization on microorganisms in the woody perennials, especially economic trees, despite the increased number of studies dealing with soil microbial community structure and function in several annual crop species (soybean [15]; barley [27]; rice [28]; maize [29]; wheat, oat and pea [30]). Moreover, the walnut genome has been sequenced [31-33], and we can thus now use genetic techniques to better study walnut-microbe interactions.

We investigated the relationship between soil chemical properties and microbial community of the rhizosphere and root endosphere of naturally grown walnut trees and those cultivated with chemical fertilization by high-throughput sequencing and structural equation model (SEM). Our study aims to determine (1) the soil chemical properties in natural and cultivated ecosystems, (2) the differences in the rhizosphere and root endosphere microbial community between natural and cultivated ecosystems, and (3) the key soil factors affecting microbial diversity and composition. The results of this study will provide a basis for rational fertilization management of perennial woody plants to promote sustainable agriculture and increase the benefits by reducing the planting cost of walnut.

\section{Materials and Methods}

\subsection{Site Description}

A long-term fertilization experiment that started in 2002 in southwestern China was used to evaluate the impact of chemical fertilizers on nuts yield, soil chemical properties, and microbial community composition. The region has a continental monsoon climate with an annual average temperature of $12-17^{\circ} \mathrm{C}$, and annual average precipitation of $856-1144 \mathrm{~mm}$. In the same experimental area, uniformly growing trees were selected for naturally grown and cultivated trees in 2002. In the first year of fertilization (2002), the same amount of organic fertilizer (organic fertilizer; $5000 \mathrm{~kg} / \mathrm{acre}$, broadcast fertilization) was applied to naturally grown and cultivated trees. In addition, the cultivated trees received chemical fertilizers (compound-fertilizer, $\mathrm{N}: \mathrm{P}_{2} \mathrm{O}_{5}: \mathrm{K}_{2} \mathrm{O}=15: 15: 15 ; 80 \mathrm{~kg} /$ acre, furrow application) in autumn. From then on (2003-2017), the naturally grown trees did not receive any type of fertilizer, whereas the cultivated trees typically received chemical fertilizers in autumn each year. The area of naturally grown trees is approximately 3-6 km away from the cultivated tree area. Other tree management measures were conducted according to "the China walnut complex standardization 
system" (LY/T 3004-2018; http://www.forestry.gov.cn). Our early experiments (from 2002 to 2017) were carried out to evaluate the effects of long-term fertilization on the yield of walnut nuts. The analyses of the walnut yield for 3 consecutive years revealed that fertilization treatments had comparably similar nut yield (not significantly different, $p>0.05$ ) that represented $232.13 \pm 14.32 \mathrm{~kg} /$ acre for naturally grown and $250.07 \pm 7.22 \mathrm{~kg} /$ acre for cultivated trees.

\subsection{Soil Sampling and Walnut Roots Collection}

The collection of soil and root samples from naturally grown and cultivated walnut trees was conducted at five locations that are the main concentrated distributed area of walnut (Chuxiong, Dali, Honghe, Lincang, and Zhaotong) in southwestern China (Figure 1). Fifteen healthy walnut trees (five trees each) at the reproductive stage were randomly selected from three replicated locations of naturally grown and cultivated trees sites in each of five geographical locations in 2018. The soil samples for each site were collected from 20 to $30 \mathrm{~cm}$ soil depth, mixed thoroughly, and passed through a 2-mm mesh to remove the plant debris and stones (Figure S1). The samples were then stored in a cool box and transported to the laboratory for the analysis of soil chemical properties. The root samples were collected (20-30 cm depth; 1-2 mm diameter) by first clearing surface debris from the base of the walnut tree and then excavating the root with an ethanol-sterilized spade. For each tree, the fine roots (1-2 $\mathrm{mm})$ were separated using sterile tweezers, and then placed into plastic bags and sealed for transport to the laboratory within a cooling box. The walnut root, which is fleshy and without root hairs, was observed by stereomicroscope (Figure S2). For rhizosphere soil, fine roots were shaken gently to remove excess soil, then roots were placed in $50 \mathrm{~mL}$ sterilized Falcon tubes containing $25 \mathrm{~mL}$ sterile Silwet L-77 amended PBS buffer (PBS-S: $130 \mathrm{mM} \mathrm{NaCl}, 7 \mathrm{mM} \mathrm{Na} \mathrm{HPO}_{4}, 3 \mathrm{mM} \mathrm{NaH} \mathrm{PO}_{4}, \mathrm{pH} 7.0,0.02 \%$ Silwet L-77), were washed on a shaking platform for $20 \mathrm{~min}$ at $180 \mathrm{rpm}$, and the rhizosphere soil was allowed to settle for $5 \mathrm{~min}$. The roots were carefully removed and transferred to new $50 \mathrm{~mL}$ sterilized Falcon tubes, and the washing buffer was centrifuged at 10,000× $g$ for $20 \mathrm{~min}$. The supernatant was discarded carefully, and the rhizosphere soil was collected, frozen in liquid nitrogen, and stored at $-80{ }^{\circ} \mathrm{C}$ until DNA extraction. For the root endosphere compartment, the epiphytes were first removed from the root surface, according to the method described by Beckers et al. (2017) [34] with some modifications. The roots were first washed with $70 \%(v / v)$ ethanol for $40 \mathrm{~s}$, followed by $5 \%$ sodium hypochlorite (with active chloride ions) for $5 \mathrm{~min}$, and then with $70 \%(v / v)$ ethanol for $30 \mathrm{~s}$. Washed root samples were rinsed three times with sterile water and dried using sterile filter paper.

\subsection{Soil Chemical Properties Analysis}

Soil samples were air-dried and analyzed for soil $\mathrm{pH}\left(\mathrm{pH}_{\mathrm{KCl}}\right)$ using a Thermo Orion-868 $\mathrm{pH}$ meter (Thermo Orion Co.; Waltham, MA, USA) in $1 \mathrm{~mol} \cdot \mathrm{L}^{-1} \mathrm{KCl}$ system. Nitrate-nitrogen $\left(\mathrm{NO}_{3}{ }^{-}\right)$, ammonium-nitrogen $\left(\mathrm{NH}_{4}{ }^{+}\right)$, and available phosphorus (AP) were extracted with $0.01 \mathrm{M}$ calcium chloride and quantified using an AutoAnalyzer 3 (SEAL Analytical GmbH, Norderstedt, Germany). The organic matter (OM) content was analyzed using the dichromate chemical oxygen demand test. All the soil samples were quantified as previously reported (Bao SD, Soil and Agricultural Chemistry Analysis, Beijing, Agriculture Publication (2000) p. 355-6). 


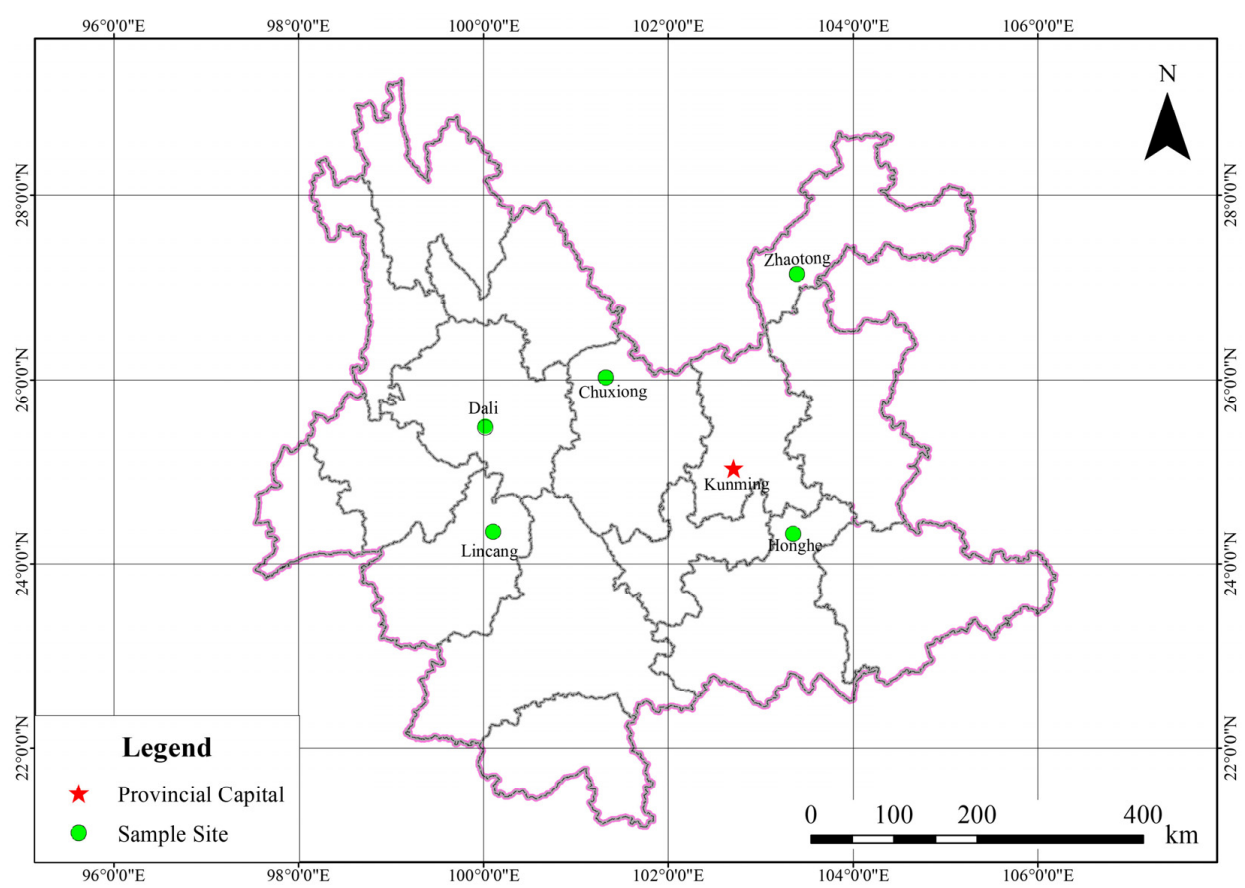

Figure 1. Map of sampling locations in the experiment areas in southwestern China. Diagram showing the collection of soil and root samples from naturally grown and cultivated walnut trees sites in each of five locations, which is indicated by the blue circle. The naturally grown and cultivated walnut trees areas are approximately 3-6 km apart, which were put in a circle in the same location. Fifteen healthy walnut trees (five trees each) at the reproductive stage were randomly selected from three replicated locations of a naturally grown and cultivated trees sites in each of five geographical locations.

\subsection{Walnut Rhizosphere and Root DNA Extraction, PCR Amplification and High-Throughput} Amplicon Sequencing

The MoBio PowerSoil DNA isolation kit (MoBio Laboratories, Carlsbad, CA, USA) was used for the extraction of DNA by following the manufacturer's instructions. A total of 20 rhizosphere (2 replicates from each naturally grown and cultivated tree site were obtained due to very little soil being adhered to the fine roots of walnut) and 30 root endosphere samples were applied to extract genomic DNA by homogenizing the samples in the DNeasy instrument for $30 \mathrm{~s}$ at a speed setting of 6.0. The extracted DNA was eluted in $50 \mu \mathrm{L}$ of elution buffer and then stored at $-80{ }^{\circ} \mathrm{C}$ for further PCR amplification. The DNA concentrations were measured with a NanoVue Plus (BIOCHROM LTD, Cambridge, UK).

The DNA from each replicate was adjusted to $30 \mathrm{ng} / \mu \mathrm{L}$ for the rhizosphere and root endosphere from five locations. Fungal diversity in the rhizosphere and root endosphere was determined by sequencing the Internal Transcribed Spacer (ITS) region 2 of the fungal ITS gene with the specific barcoded primer pair ITS3F (5'-GCATCGATGAAGAACGCAGC-3') and ITS4R (5'-TCCTCCGCTTATTGATATGC-3') [35]. The bacterial community was characterized from the rhizosphere and root endosphere by sequencing the $16 \mathrm{~S}$ rRNA V4 region with the specific barcoded primer pair 515F (5'-GTGCCAGCMGCCGCGGTAA-3') and 806R (5'-GGACTACHVGGGTWTCTAAT-3') [15]. The PCR amplifications were performed in triplicate on a Veriti thermal cycler (Applied Biosystems Veriti Thermal Cycler, Thermo Fisher Scientific, San Jose, MA, USA). The PCR products were then separated by agarose gel electrophoresis to purify the amplicons using a DNA Gel Extraction Kit (Takara, Kyoto, Japan) and pooled in equimolar concentrations before sequencing. Finally, paired-end sequencing of the bacterial and fungal amplicons was performed on an Illumina HiSeq sequencer at Guangdong Magigene Biotechnology Co. Ltd. (Guangzhou, China). 
All of the sequence data have been submitted to the National Genomics Data Center under BioProject ID PRJCA002614.

\subsection{Bioinformatic and Statistical Analyses}

Bacterial and fungal sequences were quality-trimmed using Trimmomatic v0.36 and assigned to samples based on barcodes using Quantitative Insights into Microbial Ecology (QIIME). De novo and reference-based chimera were checked, and sequences characterized as chimeric were removed. Bacterial and fungal reads were binned into operational taxonomic units (OTUs) at the $\geq 97 \%$ sequence similarity level using an open-reference OTU picking protocol in the UPARSE-pipeline [36], and the most abundant sequences from each OTU were taken as representative sequences of that OTU. Finally, the taxonomic configuration of bacterial and fungal OTUs was performed using the SILVA and UNITE databases, respectively. Bacterial OTUs representing the chloroplast or mitochondria were discarded before downstream analysis. The resulting OTU table was used to determine the taxonomic composition and for calculations of alpha- and beta-diversity. Alpha- and beta-diversity were calculated using QIIME (V1.9.1) and visualized using R software (ver. 2.1.5.3; R Development Core Team). Principal coordinate analysis ( $\mathrm{PCoA}$ ) was performed to analyze the similarities and differences among microbial communities, and linear discriminant analysis (LDA) and effect size (LEfSe) analysis were performed to identify the indicator taxa representing each group. For the LEfSe analysis, values were significant $(p<0.05)$ when the LDA score was more than 2 . Diversity metrics and soil chemical properties were compared among samples with a one-way analysis of variance (ANOVA) using SAS software (ver. 9.1; SAS Institute, Cary, NC, USA). The least significant difference test was used to evaluate results and differences were considered significant at $p<0.05$.

To identify the soil factors that have the main effects on microbiota and to provide a basis for the better management of agricultural intensification, a structural equation model (SEM) was employed to gain a mechanistic understanding of how soil chemical properties mediate alterations in soil bacterial community and fungal diversity [37]. The bacterial community (beta diversity) was obtained by principal component analysis (PCA), and the first principal component (PC1) and Shannon index of fungi (alpha diversity) were used for SEM analysis. All variables were standardized by $\mathrm{Z}$ transformation (mean $=0$, standard deviation $=1$ ). In the SEM analysis, OM is one of the main energy sources of soil microorganisms, and naturally grown trees receive OM but did not receive chemical fertilizers, whereas cultivated trees received OM in the first year and then chemical fertilizer afterwards. It was therefore assumed that fertilizers alter soil chemical properties, which in turn affects microbial community and diversity. Thus, the theoretical model assumed that (1) OM directly influences bacterial community and fungal diversity, (2) OM indirectly affects the bacterial community and fungal diversity by changing soil chemical properties, and (3) the rhizosphere directly influences the endosphere. Amos software (ver. 22.0, IBM/International Business Machines Corporation, Armonk, NY, USA) was used to construct the SEM in this study.

\section{Results}

\subsection{Soil Chemical Properties}

Soil chemical properties were distinct between naturally grown walnut trees and cultivated trees planted on field soils (Figure 2; ANOVA and LSD $p<0.05$ ). In general, $\mathrm{OM}, \mathrm{pH}_{\mathrm{kcl}}, \mathrm{TN}, \mathrm{NO}_{3}{ }^{-}$, and TP contents were significantly higher in natural soil than cultivated soil. However, the AP and $\mathrm{NH}_{4}{ }^{+}$ were significantly lower in natural soil than cultivated soil, except for at LC and ZT. Furthermore, the long-term application of chemical fertilizers in cultivated trees led to a decrease in soil $\mathrm{pH}_{\mathrm{kcl}}$ that resulted in soil acidification. 

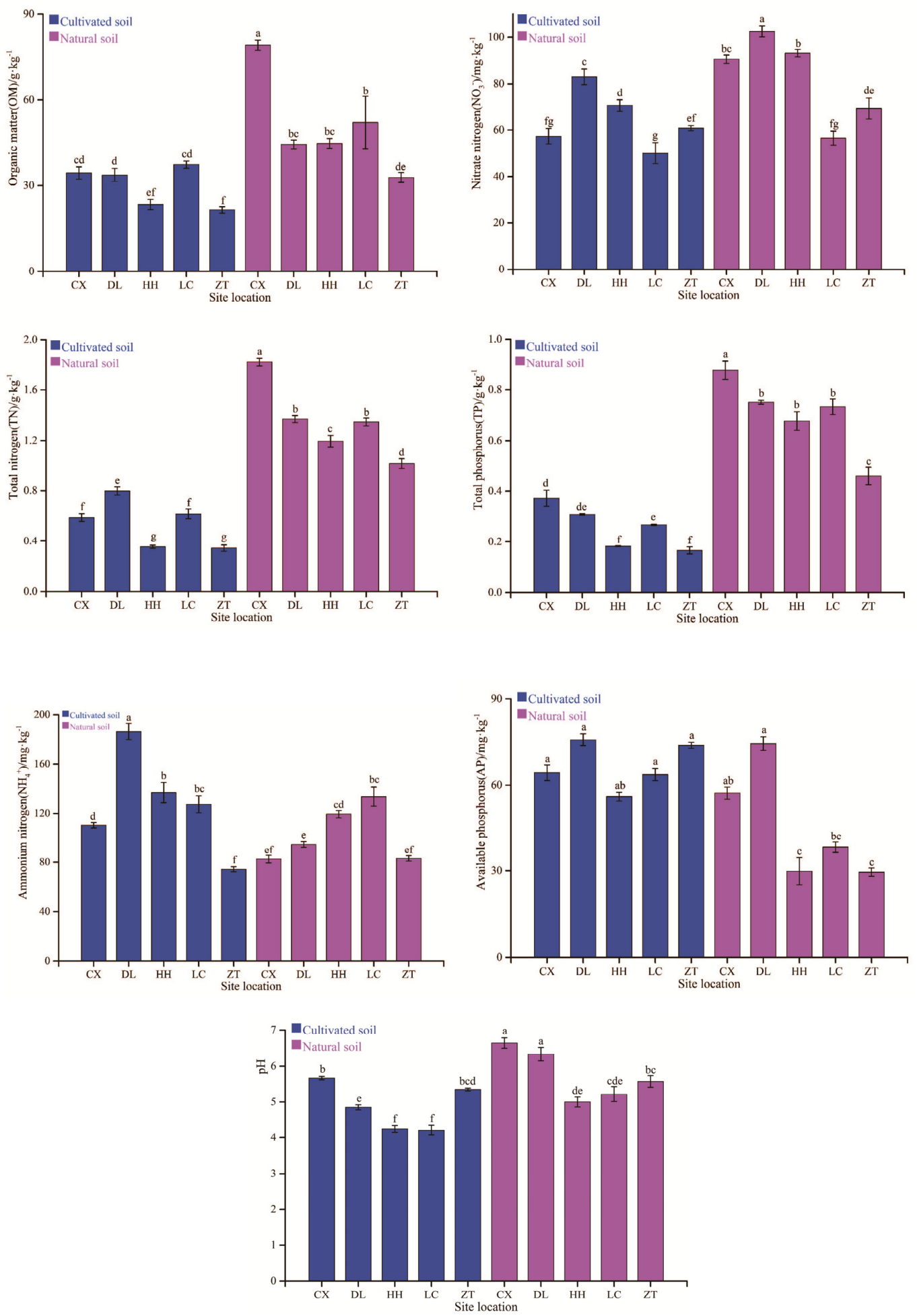

Figure 2. Soil chemical properties (mean $\pm \mathrm{SE}, n=3$, error bars indicate the standard deviation) at naturally grown and cultivated walnut trees. Different lowercase letters on each column represent significant differences $(p<0.05)$ between the natural and cultivated soil based on the least significant difference test. The blue bar chart shows the soil chemical properties of cultivated soil after fertilization, and the brown bar chart shows the soil chemical properties of natural soil in non-fertilization. CX, Chuxiong; DL, Dali; HH, Honghe; LC, Lincang; ZT, Zhaotong. 
We further estimated soil chemical properties of fertilized and non-fertilized areas according to the standard classification of soil nutrient levels in China (Table S1). OM was in Grade 2-3, TN (DL up to 4) and TP were in Grade 5-6, AP was in Grade 1 in the fertilized soil, whereas OM was in Grade 1 (ZT drops to 2), TN in Grade 3 (CX up to 2), TP in Grade 2-3 (ZT drops to 4) and AP in Grade 2 (CX, DL up to 1) in non-fertilized soil.

\subsection{Differences in Bacterial and Fungal Diversity Associated with Naturally Grown and Cultivated Trees}

The within-sample diversity ( $\alpha$-diversity) of the bacterial and fungal communities from the rhizosphere and root endosphere was estimated using Shannon's diversity index (Figure 3A,B). The Shannon diversity index values for the rhizosphere and root endosphere bacterial community were not significantly different between naturally grown and cultivated trees (LSD, $p>0.05$ ), indicating that chemical fertilization had little effect on the bacterial diversity. On the other hand, the Shannon diversity values for the rhizosphere and root endosphere fungal community were significantly higher for naturally grown trees than for cultivated trees (Figure 3B; LSD, $p<0.05$ ).
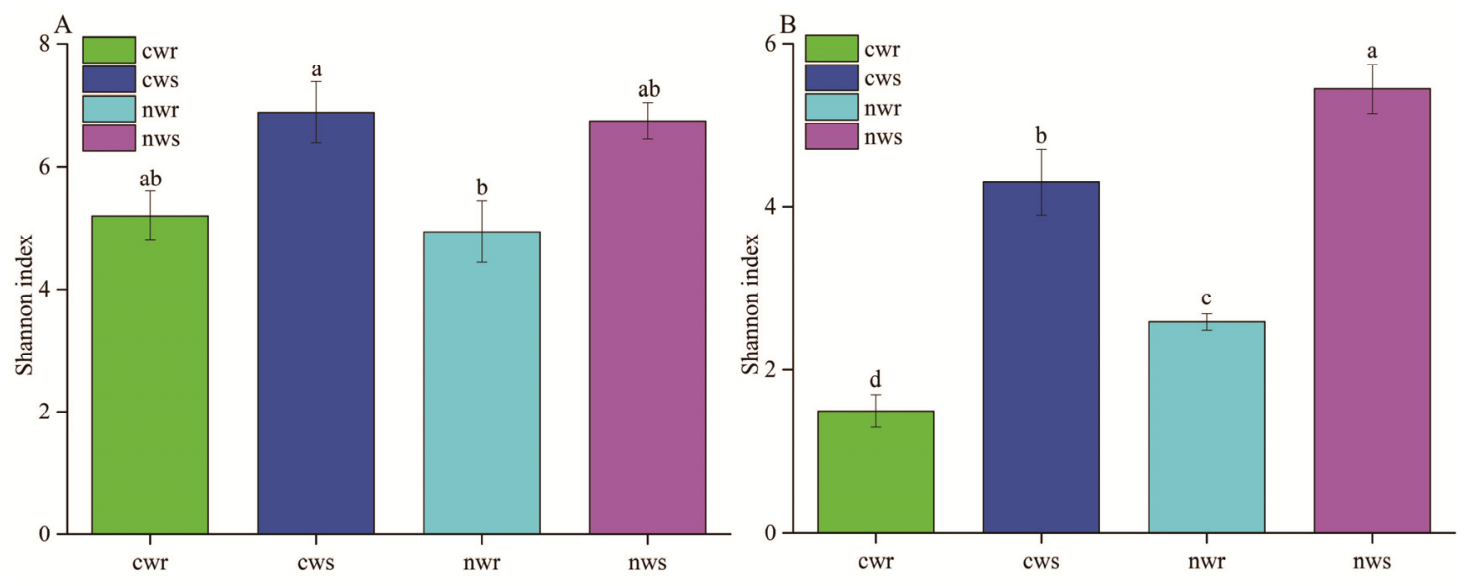

Figure 3. Shannon diversity indices of (A) bacterial and (B) fungal communities in the rhizosphere and root endosphere of naturally grown and cultivated trees. Different lowercase letters on each column represent significant differences $(p<0.05)$ between the rhizosphere and root endosphere based on the least significant difference test. cwr-cultivated tree endosphere; cws—cultivated tree rhizosphere; nwr-naturally grown tree endosphere; nws—naturally grown tree rhizosphere.

PCoA based on unweighted UniFrac distances, a metric that measures the phylogenetic relatedness of the whole community and is well suited for comparing beta-diversity patterns between complex microbial communities, was used to investigate bacterial and fungal beta-diversity in naturally grown and cultivated tree walnut system. Bacterial beta-diversity differed between the rhizosphere and root endosphere, as well as between naturally grown and cultivated trees. Principal components 1 (PC1) and 2 (PC2) explained 44.1\% and 19.1\% of the total variation, respectively (Figure 4A), indicating that chemical fertilization had important effects on the bacterial community composition. Similarly, the fungal community also differed between the endosphere and the rhizosphere, with PC1 and PC2 explaining $50.5 \%$ and $21.4 \%$ of the total variation, respectively (Figure $4 \mathrm{~B}$ ). These results indicated that chemical fertilization had an important effect on the microbial community structure and diversity of the cultivated walnut trees. 

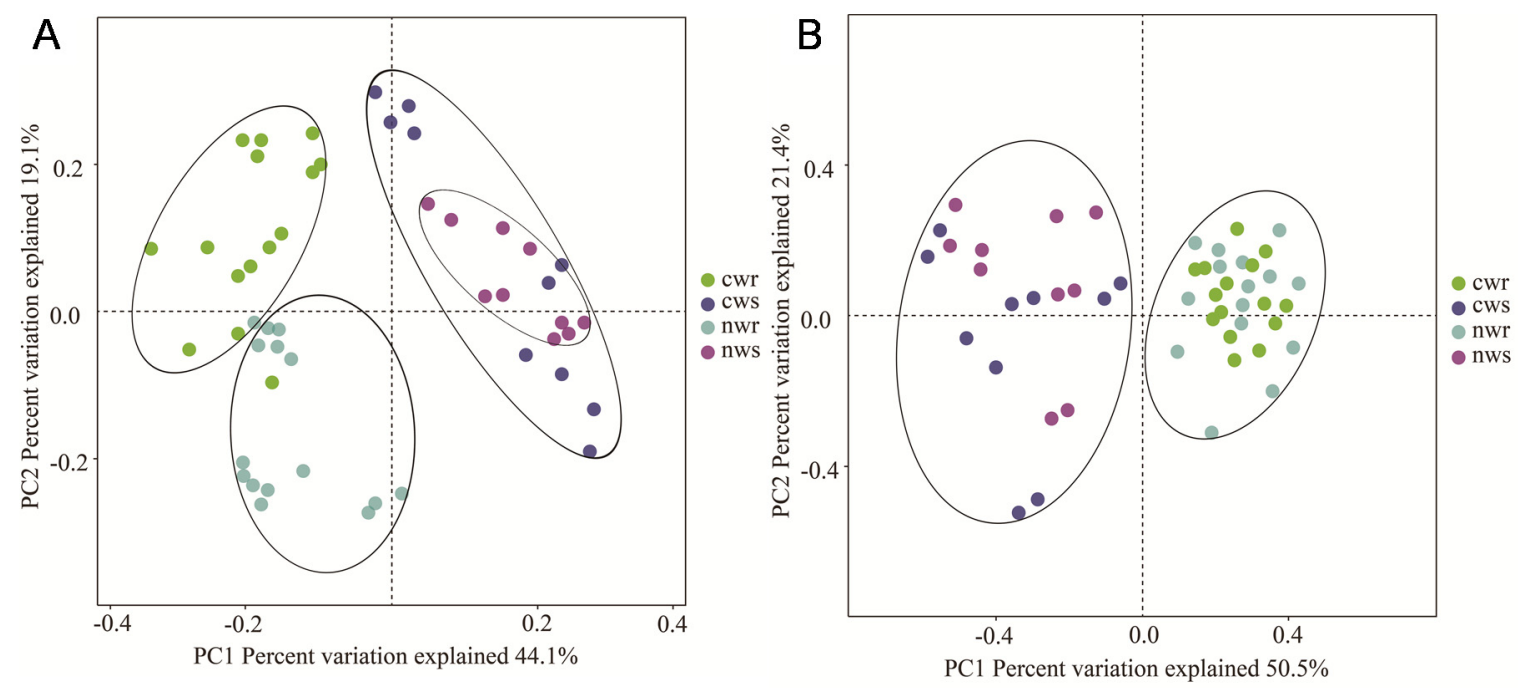

Figure 4. Principal coordinate analysis plot of the (A) bacterial and (B) fungal communities found in the rhizosphere and root endosphere of naturally grown and cultivated walnut trees. Principal components analysis (PCoA) plot of the first two principal components based on operational taxonomic units (OTUs) in the rhizosphere and root endosphere of walnut when exposed to naturally grown and cultivated walnut trees. 95\% confidence ellipses (the ANOSIM test) were shown around the samples grouped based on naturally grown and cultivated trees. cwr-cultivated tree endosphere; cws-cultivated tree rhizosphere; nwr-naturally grown tree endosphere; nws-naturally grown tree rhizosphere.

\subsection{Dominant Bacterial Taxa in Walnut Rhizosphere and Root Endosphere}

We obtained 798,445 quality-filtered reads of 16S rRNA corresponding to 21,681 OTUs in samples from cultivated trees, and 735,546 quality-filtered reads corresponding to 21,442 OTUs in samples from naturally grown trees (Table S2). These bacteria OTUs belonged to 22 phyla (Figure 5A); Proteobacteria, Acidobacteria, Planctomycetes, Actinobacteria, and Bacteroidetes were the dominant phyla in the rhizosphere and root endosphere of the walnut trees. Bacterial community composition was found to be distinct between the rhizosphere and root endosphere. The rhizosphere of naturally grown and cultivated trees were composed of Proteobacteria (54\% in naturally grown trees; $44 \%$ in cultivated trees), Acidobacteria (10\% in naturally grown trees; $12 \%$ in cultivated trees), Planctomycetes (6\% in naturally grown trees; $6 \%$ in cultivated trees), and Actinobacteria ( $4 \%$ in naturally grown trees; $5 \%$ in cultivated trees). Similarly, the root endosphere of naturally grown and cultivated trees was composed of Proteobacteria (63\% in naturally grown trees; $62 \%$ in cultivated trees), Acidobacteria ( $5 \%$ in naturally grown trees; $7 \%$ in cultivated trees), Planctomycetes (15\% in naturally grown trees; $4 \%$ in cultivated trees), and Actinobacteria ( $7 \%$ in naturally grown trees; $10 \%$ in cultivated trees). The relative abundance of phylum Proteobacteria was increased in the root endosphere than the rhizosphere of naturally grown and cultivated walnut trees. In contrast, Acidobacteria were decreased in root endosphere than the rhizosphere of naturally and cultivated walnut trees.

We then analyzed the relative abundance of bacteria in the rhizosphere and root endosphere of naturally grown and cultivated trees at the genus level (Figure 6A). The 30 most abundant genera associated with both naturally grown and cultivated trees belonged to 9 bacterial phyla. Burkholderia was the most abundant genus in the rhizosphere and root endosphere of both tree types. Pseudomonas and Candidatus_Solibacter were abundant in the rhizosphere and root endosphere of naturally grown trees, whereas Pirellula, Bdellovibrio, Klebsiella, Acidothermus, and Flavobacterium were abundant in the rhizosphere and root endosphere of cultivated trees. Cluster analysis results revealed that the bacterial communities differed between naturally grown and cultivated trees, implying that the cultivation process affected the bacterial community composition. 

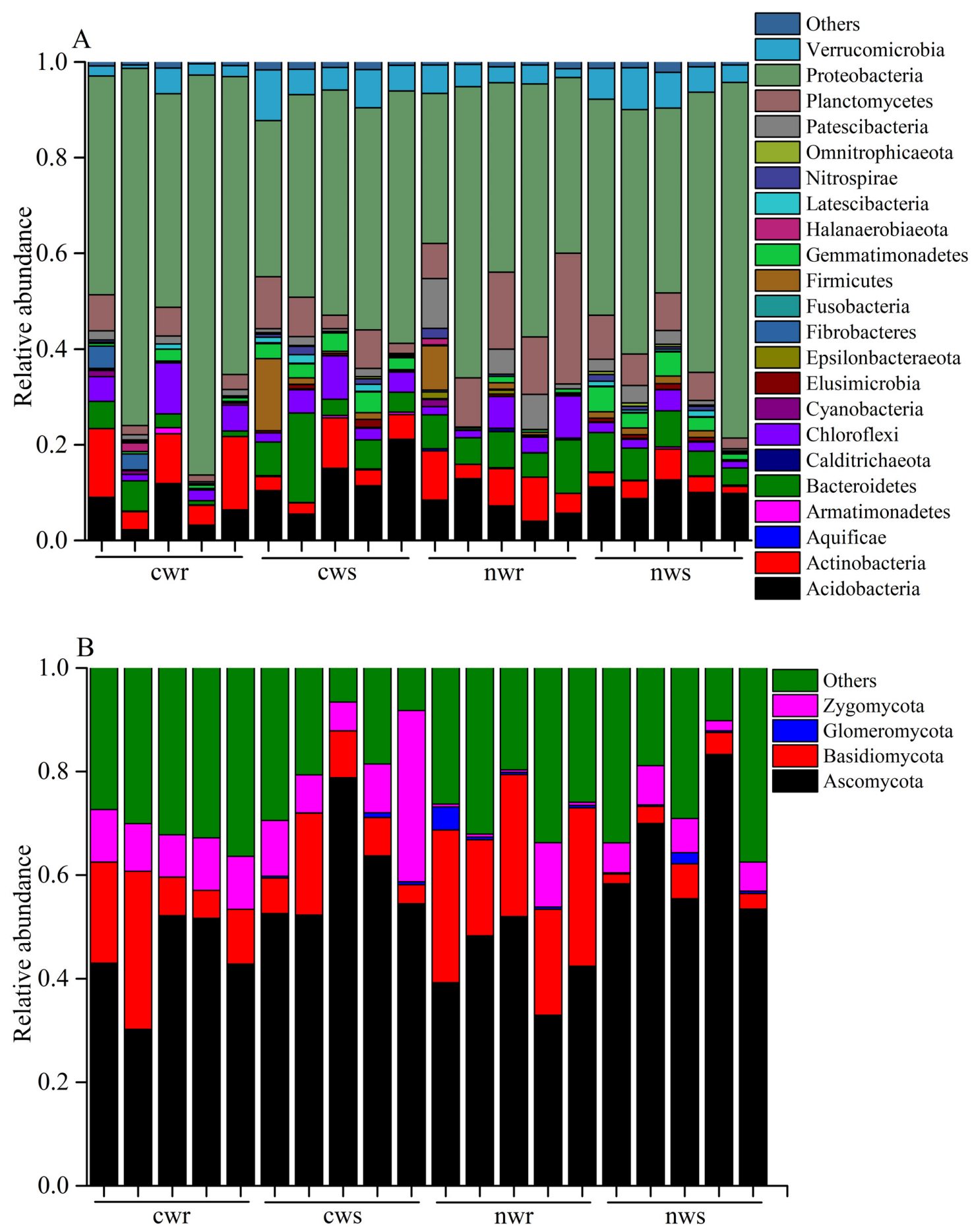

Figure 5. Relative abundance of (A) bacteria and (B) fungi at the phylum level in the rhizosphere and root endosphere of naturally grown and cultivated walnut trees. cwr-cultivated tree endosphere; cws-cultivated tree rhizosphere; nwr-naturally grown tree endosphere; nws—naturally grown tree rhizosphere. 
A

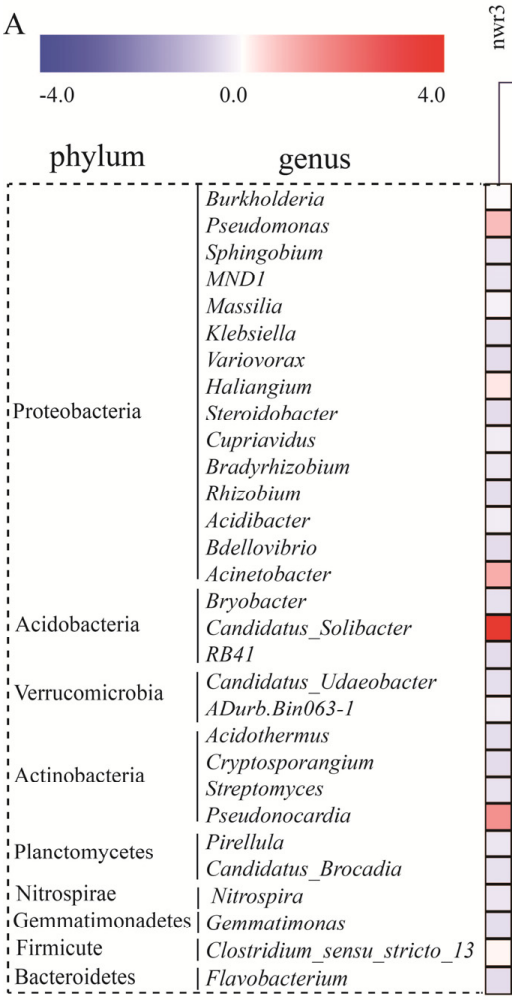

B

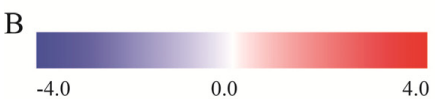

phylum

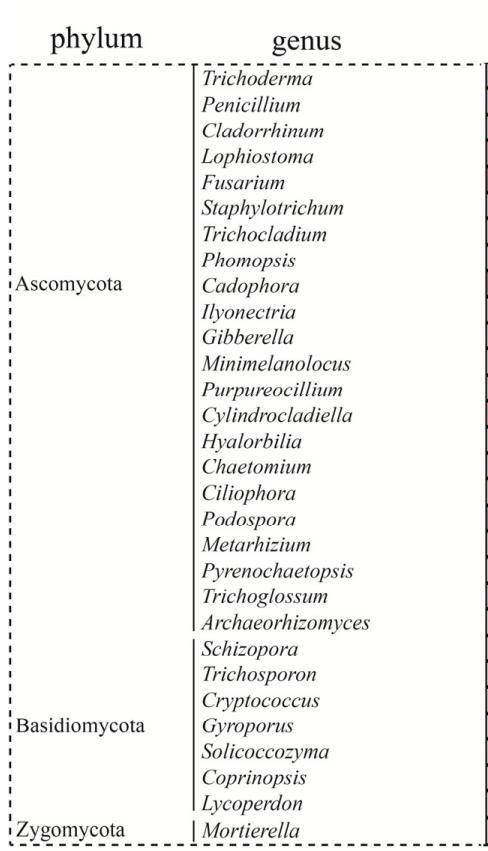

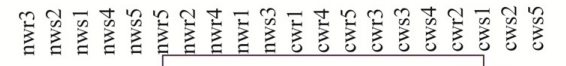

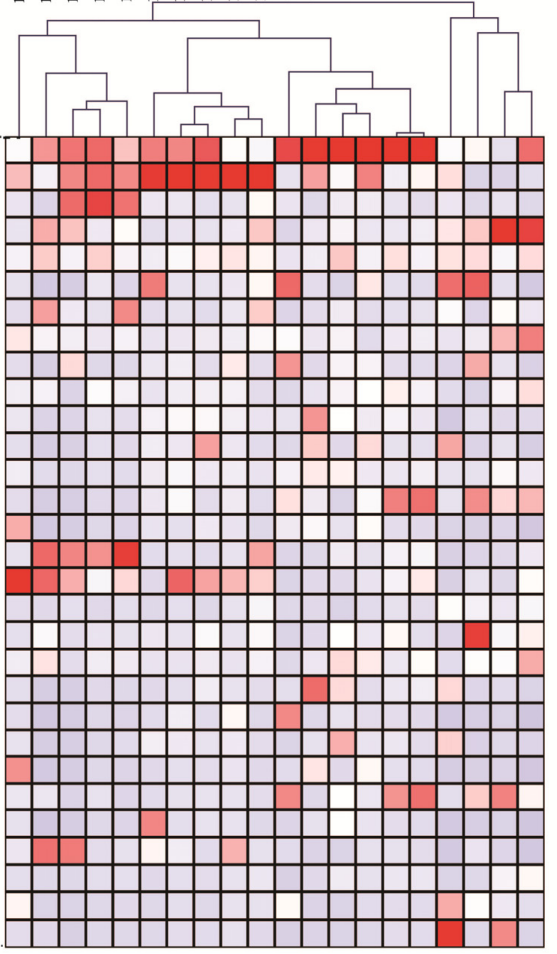

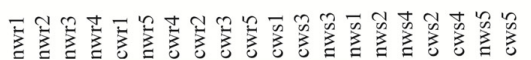

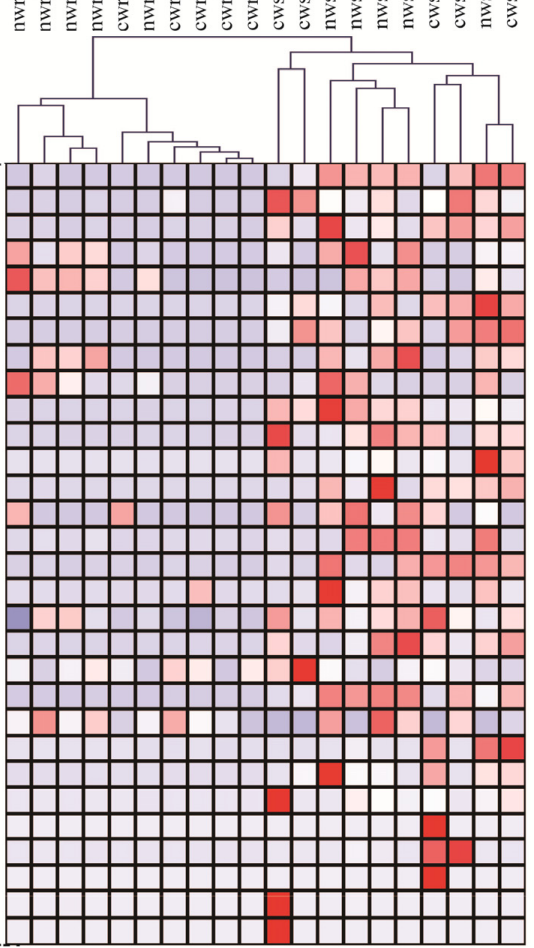

Figure 6. The 30 most abundant (A) bacterial and (B) fungal taxa in the rhizosphere and root endosphere across all sampling locations. Heatmap representing the hierarchical clustering of naturally grown and cultivated trees samples as well as relative changes in the abundance of bacterial and fungal genera inhabiting the rhizosphere and root endosphere of walnut. The red color indicates higher relative abundance, whereas the blue color indicates the lower the abundance. 
The LEfSe analysis was used to identify the main taxa that contributed to community differences. We identified 55 indicator taxa belonging to 10 bacterial phyla (Figure 7A) that significantly distinguished the bacterial community associated with cultivated trees from the community associated with naturally grown trees $(p<0.05$, LDA score $>2)$. Eight genera within Bacteroidetes, Gemmatimonadetes, Nitrospirae, and Patescibacteria were indicators of the bacterial rhizosphere community of cultivated trees, whereas Gemmatimonas and Nitrospira within Gemmatimonadetes were indicators of the bacterial rhizosphere community of naturally grown trees. Seven phyla and eight genera distinguished the bacterial rhizosphere community of naturally grown trees from that of cultivated trees. Specifically, Candidatus_Solibacter and Nitrospira were more abundant in the rhizosphere of naturally grown trees. Conversely, four phyla and three genera distinguished the bacterial rhizosphere community of cultivated trees from that of naturally grown trees. Of these, Bdellovibrio and Pajaroellobacter were more abundant in the rhizosphere of cultivated trees. Additionally, two taxa within Actinobacteria and Cyanobacteria, including the family Moraxellaceae, were indicators of the bacterial endosphere community of cultivated trees, whereas two orders within Proteobacteria, Pseudomonadales and Betaproteobacteriales were indicators of the bacterial endosphere community of naturally grown trees (Table S3).

\subsection{Dominant Fungal Taxa in the Walnut Rhizosphere and Root Endosphere}

The four dominant fungal phyla in the rhizosphere and root endosphere were Ascomycota, Basidiomycota, Glomeromycota, and Zygomycota (Figure 5B). Ascomycota comprised $43 \%$ and $44 \%$, and Basidiomycota comprised $25 \%$ and $14 \%$ of the fungal communities in the root endosphere of naturally grown and cultivated trees, respectively. Similarly, Ascomycota comprised $64 \%$ and $60 \%$, and Basidiomycota comprised $9 \%$ and 3\% of the fungal communities in the rhizosphere of naturally grown and cultivated trees, respectively. Specifically, Ascomycota was dominant in the rhizosphere, and Basidiomycota had a higher relative abundance in the root endosphere. Moreover, the relative abundance of Basidiomycota was higher in the rhizosphere and root endosphere of the naturally grown trees than the cultivated walnut trees.

The 30 most abundant fungal genera in all samples belonged to Ascomycota, Basidiomycota, and Zygomycota (Figure 6B). The rhizosphere of naturally grown trees was mainly dominated by Trichoderma, Lophiostoma, Phomopsis, Ilyonectria, Purpureocillium, Cylindrocladiella, Hyalorbilia, Chaetomium, and Trichoglossum. These genera were relatively less abundant in the rhizosphere of cultivated trees. Lophiostoma and Purpureocillium were the most abundant genera in the root endosphere of both tree types. In addition, the LEfSe analysis identified 36 indicator taxa for the fungal communities associated with walnut trees (Figure 7B). For instance, Tremellomycetes, Agaricomycetes, and Mortierella were less abundant, whereas Trichocladium, Trichoderma, and Cylindrocladiella were more abundant in the rhizosphere of naturally grown trees than in the rhizosphere of cultivated trees. These differentially abundant taxa could be regarded as potential microbe biomarkers (Table S4). 

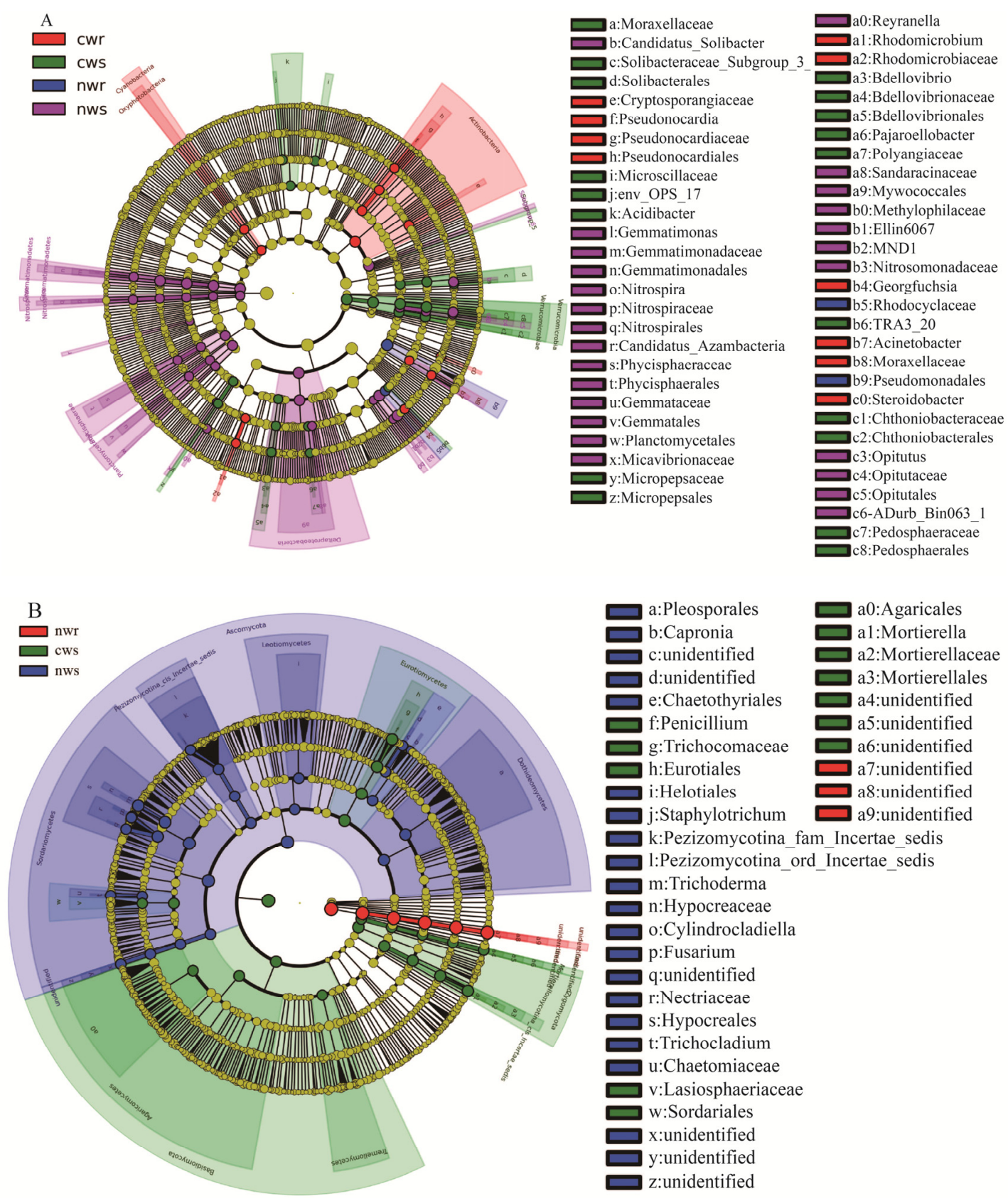

Figure 7. Bacterial (A) and fungal (B) taxa that contributed most to differences in microbial community composition. The linear discriminant analysis (LDA) effect size (LEfSe) analysis was performed to identify the indicator taxa representing each group, and the values were significant $(p<0.05)$ when the LDA score was more than 2.

\subsection{Influential Factors on Bacterial Community and Fungal Diversity}

To determine the interactive effect of soil chemical properties on bacterial community and fungal diversity, an SEM was constructed, and the relationship models for the $\mathrm{OM}, \mathrm{pH}_{\mathrm{KCl}}, \mathrm{NO}_{3}{ }^{-}, \mathrm{NH}_{4}{ }^{+}$, and AP relative to the bacterial community and fungal diversity are shown in Figure 8. The results showed that this model was non-recursive, and accounted for $38 \%$ of the variation in $\mathrm{pH}_{\mathrm{KCl}}, 26.2 \%$ in $\mathrm{AP}, 27.1 \%$ in $\mathrm{NO}_{3}{ }^{-}, 43.7 \%$ in $\mathrm{NH}_{4}{ }^{+}$, and $28.9 \%$ and $71.5 \%$ in the bacterial community of the rhizosphere and root endosphere, respectively (Figure 8A). The improved model had a good fit to the data $\left(\chi^{2}=0.796\right.$, chi-square; $p=0.496, \mathrm{GFI}=0.918$, goodness-of-fit index; AIC $=52.33$, Akaike information criteria; and RMSEA $=0.000<0.05$, root-mean-square errors of approximation), which also 
indicates that the hypothesis model was well adapted to the observation data. This model shows that there was a negative relationship between the $\mathrm{NH}_{4}{ }^{+}$and the bacterial community of the rhizosphere and root endosphere, with correlation coefficients of -0.621 and -0.825 , respectively. This indicates that fertilization significantly affected the bacterial community of the rhizosphere and root endosphere because of the increased $\mathrm{NH}_{4}{ }^{+}$content and decreased soil $\mathrm{pH}_{\mathrm{KCl}}$. This model also showed that there was a negative relationship between the $\mathrm{NH}_{4}{ }^{+}$and $\mathrm{pH}_{\mathrm{KCl}}$, with a correlation coefficient of -0.615 , and a positive relationship between the $\mathrm{OM}$ and $\mathrm{pH}_{\mathrm{KCl}}$ with a correlation coefficient of 0.617 . This indicates that natural ecosystems had a higher OM content than cultivated systems, which indirectly affected the bacterial community of the rhizosphere and root endosphere by $\mathrm{pH}_{\mathrm{KCl}}$. This model further indicates that there was a positive interaction between the rhizosphere and root endosphere bacterial community, with a correlation coefficient of $0.515(p<0.05)$.
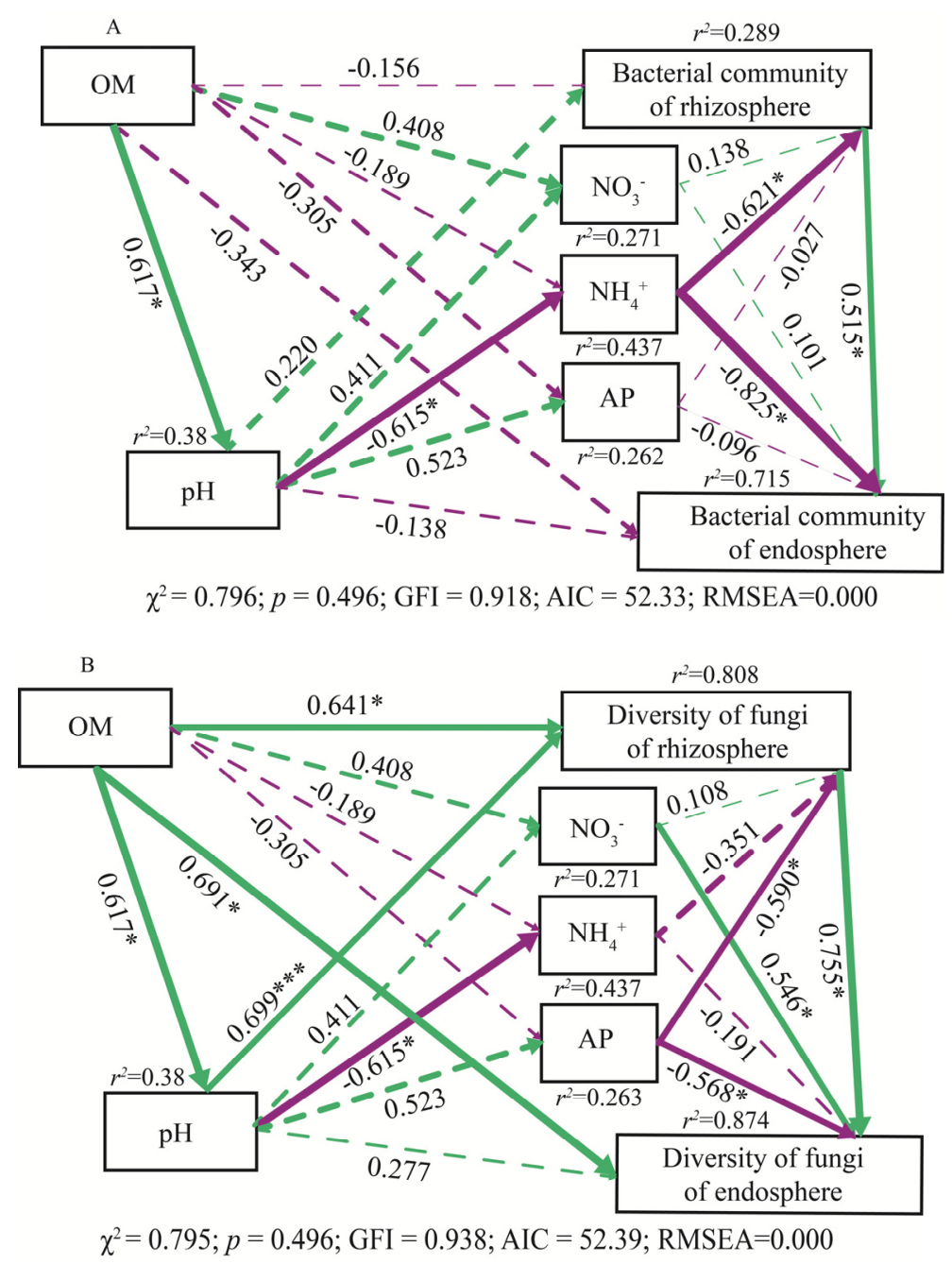

Figure 8. Structural equation model (SEM) shows influential factors of soil properties on the bacterial community (A) and fungal diversity (B). Green and brown arrows indicate positive and negative relationships, respectively. Significant levels are denoted ${ }^{*} p<0.05,{ }^{* *} p<0.01,{ }^{* * *} p<0.001$. Solid and dotted lines represent significant and insignificant differences, respectively. $r^{2}$ values indicate the proportion of variance explained for each variable. The low chi-square $\left(\chi^{2}\right)$, nonsignificant probability level $(p>0.05)$, high goodness-of-fit index (GFI >0.90), low Akaike information criteria (AIC), and low root-mean-square errors of approximation (RMSEA < 0.05) listed below the SEMs indicate that our data matches the hypothetical models. 
We further quantified the contribution of each potentially influential factor (including $\mathrm{OM}, \mathrm{pH}_{\mathrm{KCl}}$, $\mathrm{NO}_{3}{ }^{-}, \mathrm{NH}_{4}{ }^{+}$, and $\left.\mathrm{AP}\right)$ to the significant reduction $(p<0.05)$ in the fungal diversity in the rhizosphere and root endosphere induced by fertilization, when compared with naturally walnut trees during non-fertilization. The improved model proved a good fit to the data $\left(\chi^{2}=0.795\right.$, chi-square; $p=0.496$, $\mathrm{GFI}=0.938$, goodness-of-fit index; $\mathrm{AIC}=52.39$, Akaike information criteria; and $\mathrm{RMSEA}=0.000<0.05$, root-mean-square errors of approximation), and the results showed that the model was reasonable and acceptable (Figure 8B). There was a positive relationship between the $\mathrm{OM}$ and the fungal diversity of the rhizosphere and root endosphere, with correlation coefficients of 0.641 and 0.691 . This result indicates that the natural ecosystems significantly affected the fungal diversity between the rhizosphere and root endosphere because of the increased OM content and improved soil acidity. AP was the dominant control on fungal diversity in the rhizosphere and root endosphere, with correlation coefficients of -0.59 and -0.568 . This indicates that the cultivated walnut trees typically receive phosphorus fertilizer, which is linked to a reduction in fungal diversity. This model further indicates that there was a positive interaction between the rhizosphere and root endosphere fungal community, with a correlation coefficient of $0.755(p<0.05)$.

\section{Discussion}

Soil nutrients are the foundation of plant growth, but the addition of large amounts of chemical fertilizers to the soil results in environmental pollution and higher planting cost [25]. Unlike other woody plants, economic trees require a lot of energy to produce large amounts of nuts in addition to maintaining normal tree growth. Therefore, good soil structure and soil fertility are essential for stable and high nut yields. However, our understanding of the chemical fertilizers to alter soil chemical and microbiological properties in woody plants is still limited. Our early experiments to evaluate the effects of long-term chemical fertilization on the yield of walnut nuts for 3 consecutive years indicated that the chemical fertilization treatments had comparably similar nuts yield for cultivated trees $(250.07 \pm 7.22 \mathrm{~kg} /$ acre; not significantly different, $p>0.05)$ to naturally grown walnut trees $(232.13 \pm 14.32 \mathrm{~kg} /$ acre $)$.

The microbial community of annual crops varies greatly due to the short growth period [38,39], while that of perennial woody plants may be stable due to the longer life cycle [40]. The microbial community composition has shown strong responses to site location, soil depth, and may be inherited in certain plant species $[41,42]$. In the current study, our results revealed high bacterial and fungal diversity in both the rhizosphere and root endosphere of walnut trees (Figure 3); however, the bacterial diversity in the rhizosphere samples was apparently more (but not significantly different) than in the root endosphere (Figure 3A). The rhizosphere has been reported to contain $10^{11}$ microbial cells per gram of root biomass and more than 30,000 bacterial OTUs [43]; therefore, the diverse microbes inhabiting the rhizosphere have a key role in plant nutrition, growth promotion, and disease protection [44-48]. We found that long-term fertilization significantly influenced the bacterial community composition (Figure 4A) but did not influence its diversity (Figure 3A) relative to non-fertilization, and similar conclusions have demonstrated that inorganic nitrogen fertilization changes soil bacterial (and fungal) community composition [49]. Proteobacteria, Actinobacteria, and Acidobacteria were identified as the predominant bacterial phyla in all samples (Figure 5A), and these predominant bacterial phyla have been reported to improve nitrogen use efficiency and promote plant growth $[39,50,51]$. The proportion of Proteobacteria was higher in the rhizosphere and root endosphere of naturally grown trees than cultivated trees, and Actinobacteria and Acidobacteria were less diverse in the endosphere of naturally grown trees than in that of cultivated trees. This result shows that the roots of naturally grown walnut recruited a higher proportion of nitrogen cycle-related bacteria and PGPR (Figures 5A and 6A), indicating that the nitrogen transformation process is probably more efficient in the root environment of naturally grown than cultivated trees. We speculate that beneficial bacteria transform organic nitrogen into nitrate and ammonium so that it can be efficiently absorbed by walnut roots in natural ecosystems. It has been previously concluded that the abundance of Proteobacteria significantly increases in 
response to the addition of chemical fertilizer [52], which differs from our results. High levels of $\mathrm{N}$ fertilization, especially $\mathrm{NH}_{4}{ }^{+}$, can drive soil acidification as a result of the ammonium ion hydrolyzes to increase soil hydrogen ion and, thus, the negative effects of $\mathrm{N}$ addition on the soil acidity [53]. It is well-known that soil acidification often causes reduced soil nutrient availability and destroys the soil structure [54,55]. As we discussed, the application of long-term chemical fertilizer significantly altered soil fertility and the abundance of beneficial microbiota, while avoiding the use of chemical fertilization increased the $\mathrm{OM}, \mathrm{TN}, \mathrm{NO}_{3}{ }^{-}$, and $\mathrm{TP}$ contents (Figure 2) in naturally grown trees. Therefore, managing the beneficial microbiota is crucial for litter decomposition and the provision of soil OM and mineral nutrition to plants [56]. In conclusion, this study has shown that long-term fertilization directly and indirectly affects soil fertility and microbial community composition, specifically that Proteobacteria are more diverse in the rhizosphere and root endosphere of the naturally grown trees and Acidobacteria in cultivated trees, which is consistent with the findings of Castro et al. [57] and Gottel et al. [58]. Therefore, chemical fertilizers will not increase the abundance of Proteobacteria unless it improves soil fertility and vice versa. These findings support the hypothesis that soil microbiota provide an important ecosystem service in plant nutrient uptake and soil nutrient cycle in reasonable agricultural ecosystems.

Furthermore, at the genus level, the bacterial community in the rhizosphere and root endosphere differed between naturally grown and cultivated walnut trees (Figure 6A). The LEfSe analysis revealed several taxa to be keystone taxa in naturally grown and cultivated walnut trees, which was linked to special functions. Some of the taxa that were more abundant when associated with naturally grown trees are important to walnut health and growth. For example, Nitrospira spp. are key nitrite-oxidizing bacteria [59], Pseudomonas spp. are rhizobacteria that promote plant growth [60], Candidatus_Solibacter bacteria decomposes OM in the soil, thus improving soil quality [61], and Burkholderia can be used as a biological pesticide to prevent infections by phytopathogens [62] in naturally grown trees. It has been reported that the relative abundance of Burkholderia and Nitrospira spp. were greater in non-fertilized soil than in fertilized soil $[63,64]$. In addition, Pseudomonadales, which have previously been reported to be keystone taxa in the endosphere, carry out symbiotic nitrogen fixation and provide nitrogen to plants [65]. In conclusion, the root microbiota become one of the major determinants of plant growth in the naturally grown trees $[66,67]$. In contrast, bacteria that negatively affect plant growth, such as Moraxellaceae, Pirellula, and Bdellovibrio, are abundant in the rhizosphere and root endosphere of cultivated trees [68]. These results reveal that natural ecosystems might have availed nitrogen fixation and enriched specific groups of nitrogen fixers, whereas cultivated trees might have selected against beneficial microbiota but enriched pathogens. Taken together with previous research, our results reveal that long-term avoidance of chemical fertilization was more favorable than fertilization in shaping the beneficial bacterial community composition and improving soil fertility for perennial economic trees, highlighting the vital importance of suitable management strategies.

Fungal community composition in the citrus rhizosphere was reported to be similar among field samples [69]. In this study, however, we found that long-term fertilization significantly influenced fungal diversity (Figure 3B) but did not influence its community composition (Figure 4B) compared with non-fertilization. The Shannon diversity index was higher for fungal communities in the rhizosphere and root endosphere of naturally grown trees compared with those in the rhizosphere and root endosphere of cultivated trees. At the genus level, the relative abundance of fungi for Trichoderma, Lophiostoma, Phomopsis, Ilyonectria, Purpureocillium, Cylindrocladiella, Hyalorbilia, Chaetomium, and Trichoglossum (all Ascomycota) indicate they are sensitive to fertilization, as their proportion decreased in response to chemical fertilization. These fungi play an important role in tree growth, soil nutrient cycling, and disease protection. For instance, Trichoderma and Purpureocillium are potential biocontrol agents of plant pathogens [70,71], and some species of Phomopsis promotes the growth and yield of the host plant, reduces fertilization and can be used as a biocontrol agent $[72,73]$. The naturally grown walnut trees were not treated with chemical fertilizer, and thus the soil around these trees supported a higher fungal diversity, as previously observed by Bossio et al. [74] and Xu et al. [75]. Furthermore, the Shannon index of the endosphere was positively correlated with the Shannon index 
of the rhizosphere $\left(r^{2}=0.755^{*}\right)$. These results imply that the recruitment of microbes from the rhizosphere to the root endosphere is dependent on the microbes available in the rhizosphere $[76,77]$. Therefore, walnut status was correlated with the community composition of associated microbes, indicating that increases in walnut growth could be attributed to the higher nutrient uptake rates and stronger anti-pathogen defenses facilitated by the microbial community associated with naturally grown trees [78]. Thus, soil microbes play important roles in plant growth and nutrient availability. Although microbial functions can be taxon-specific [79], it remains necessary to determine whether it is the entire microbiome or specific interactions that affect plant health the most.

As mentioned above, long-term chemical fertilization can influence soil chemical properties by increasing $\mathrm{NH}_{4}{ }^{+}$and $\mathrm{AP}$ contents, whereas non-fertilization increased the $\mathrm{OM}, \mathrm{TN}, \mathrm{NO}_{3}{ }^{-}$, and TP contents. These changes could be partly explained by soil microbiota in natural ecosystems, whose activities have shown to be critical to the function of these nutrient cycles and uptakes $[8,80]$. However, the fertilizer that is applied to the soil can be absorbed and transported by plants or remain in the soil [81], but excessive mineral fertilizers have been shown to change protist [82], bacterial [83], and fungal communities [84], and also affect soil enzyme activities [85]. Therefore, a lack of an increased plant yield after chemical fertilizer applications may not only be linked to the soil chemistry but also to the soil biology. Consequently, more research is needed to elucidate why fungal diversity was lower, and bacterial community composition was different in cultivated trees compared with natural trees. In our study, an SEM was used to evaluate relationships between microbiota and soil chemical properties (Figure 8). The $\mathrm{NH}_{4}{ }^{+}$and AP contents had a significant negative relationship with the bacterial community and fungal diversity of both the rhizosphere and root endosphere (Figure 8), respectively. However, the OM content had a significant positive relationship with soil $\mathrm{pH}$ and the fungal diversity of both the rhizosphere and root endosphere. These results indicate that the natural ecosystems significantly affect fungal diversity between the rhizosphere and root endosphere through beneficial microbiota to increased OM content that reducing soil acidification [26]. Moreover, the long-term application of fertilizer in walnut orchards resulted in a large amount of $\mathrm{NH}_{4}{ }^{+}$and AP residue, which changes the bacterial community and reduces fungal diversity. It is likely that some microbial taxa might have been negatively impacted by fertilizer input in cultivated areas, whereas more competitive taxa might have thrived in this environment, thus changing microbial community composition [86]. Thus, in the process of walnut planting, the application of chemical fertilizer should be moderated, which is consistent with the conclusion of Tahovská et al. (2020) [87], so that it does not cause soil acidification and the soil microbial community has time to adapt through structural and functional changes. Appropriate agricultural management of perennial woody plants should conserve soil microbiota and allow soil microbes to be recruited into the rhizosphere and root endosphere $[88,89]$. This information will help with developing better soil management practices for walnut management and elucidating the mechanisms of microbiota establishment in the walnut rhizosphere and root endosphere.

\section{Conclusions}

In our study, a comprehensive understanding of the impact of the long-term fertilization on the diversity and composition of rhizosphere and root endosphere microbiota has the potential to help guide and inform efforts to improve soil health in the face of increasing chemical fertilizer use. The results of this study reveal that there are different soil chemical and microbiological properties between natural and cultivated ecosystems. We found that long-term fertilization caused excessive $\mathrm{NH}_{4}{ }^{+}$and AP residues and soil acidification, reduced fungal diversity, and altered the bacterial community structure. Our work not only provides evidence that microbiota composition is affected by fertilization but also shows that unfavorable and or pathogenic microbiota may increase. Moreover, the rhizosphere and root endosphere of naturally grown trees hosted a higher fungal diversity and more beneficial bacterial taxa, and its associated microbiota had specific roles in soil nutrient cycling and plant growth. We suggest that the development of an organic cultivation mode of reducing the 
application of chemical fertilizer and reasonable inputs of organic fertilizers according to the soil fertility level are likely to improve economic benefits while protecting the environment.

Supplementary Materials: The following are available online at http://www.mdpi.com/2076-2607/8/5/694/s1, Figure S1: The samples collection approach used for collecting walnut tree bulk soil, rhizosphere, and fine roots. Figure S2: Root structure of walnut under stereomicroscope (fleshy and without root hairs). Table S1: Standard of soil nutrient classification in China. Table S2: Summary of 16S and ITS reads in the rhizosphere and root endosphere (mean \pm SE, $n=5$ ). Table S3: The linear discriminant analysis (LDA) effect size (LEfSe) analysis was performed to identify the indicator of bacterial taxa representing each group, and the values were significant $(p<0.05)$ when the LDA score was more than 2. Table S4: The linear discriminant analysis (LDA) effect size (LEfSe) analysis was performed to identify the indicator of fungal taxa representing each group, and the values were significant $(p<0.05)$ when the LDA score was more than 2.

Author Contributions: Y.-C.B. and M.H.; data curation, methodology, formal analysis, writing-original draft; Y.-Y.C.; software, formal analysis; B.L., J.-P.Z., and X.-S.L.; resources; X.-B.S. and D.P.; funding acquisition; D.P.; project administration, writing - review and editing. All authors have read and agreed to the published version of the manuscript.

Acknowledgments: This work was finally supported by the National Key Research and Development Program of China (Grant numbers: 2018YFD1000604) and the Basal Research Fund of Central Public Welfare Scientific Institution of Chinese Academy of Forestry (Grant numbers: CAFYBB2019ZY001). The authors are indebted to Zhi-Bin Luo for suggestions leading to the improvement of the manuscript.

Conflicts of Interest: The authors declare no conflict of interest.

\section{References}

1. McLaughlin, A.; Mineau, P. The impact of agricultural practices on biodiversity. Agric. Ecosyst. Environ. 1995, 55, 201-212. [CrossRef]

2. Chen, X.P.; Cui, Z.L.; Fan, M.S.; Vitousek, P.; Zhao, M.; Ma, W.Q.; Wang, Z.L.; Zhang, W.J.; Yan, X.Y.; Yang, J.C.; et al. Producing more grain with lower environmental costs. Nature 2014, 514, 486-489. [CrossRef] [PubMed]

3. Cui, Z.L.; Zhang, H.Y.; Chen, X.P.; Zhang, C.P.; Ma, W.Q.; Huang, C.D.; Zhang, W.F.; Mi, G.H.; Miao, Y.X.; Li, X.L.; et al. Pursuing sustainable productivity with millions of smallholder farmers. Nature 2018, 555, 363-366. [CrossRef] [PubMed]

4. Tilman, D.; Fargione, J.; Wolff, B.; D’Antonio, C.M.; Dobson, A.; Howarth, R.W.; Schlesinger, W.H.; Simberloff, D.; Swackhamer, D.L. Forecasting agriculturally driven global environmental change. Science 2001, 292, 281-284. [CrossRef] [PubMed]

5. Barłóg, P.; Grzebisz, W. Effect of timing and nitrogen fertilizer application on winter oilseed rape (Brassica napus L.). II. Nitrogen uptake dynamics and fertilizer efficiency. J. Agron. Crop. Sci. 2004, 190, 314-323. [CrossRef]

6. Bahram, M.; Hildebrand, F.; Forslund, S.K.; Anderson, J.L.; Soudzilovskaia, N.A.; Bodegom, P.M.; Bengtsson-Palme, J.; Anslan, S.; Coelho, L.P.; Harend, H.; et al. Structure and function of the global topsoil microbiome. Nature 2018, 560, 233-237. [CrossRef]

7. Zheng, F.; Zhu, D.; Giles, M.; Daniell, T.; Neilson, R.; Zhu, Y.G.; Yang, X.R. Mineral and organic fertilization alters the microbiome of a soil nematode Dorylaimusstagnalis and its resistome. Sci. Total. Environ. 2019, 680, 70-78. [CrossRef]

8. Falkowski, P.G.; Fenchel, T.; Delong, E.F. The microbial engines that drive Earth's biogeochemical cycles. Science 2008, 320, 1034-1039. [CrossRef]

9. Ikoyi, I.; Fowler, A.; Schmalenberger, A. One-time phosphate fertilizer application to grassland columns modifies the soil microbiota and limits its role in ecosystem services. Sci. Total. Environ. 2018, 630, 849-858. [CrossRef]

10. Wu, B.; Hussain, M.; Zhang, W.W.; Stadler, M.; Liu, X.Z.; Xiang, M.C. Current insights into fungal species diversity and perspective on naming the environmental DNA sequences of fungi. Mycology 2019, 10, 127-140. [CrossRef]

11. Rolli, E.; Marasco, R.; Vigani, G.; Ettoumi, B.; Mapelli, F.; Deangelis, M.L.; Gandolfi, C.; Casati, E.; Previtali, F.; Gerbino, R.; et al. Improved plant resistance to drought is promoted by the root-associated microbiome as a water stress-dependent trait. Environ. Microbiol. 2015, 17, 316-331. [CrossRef] [PubMed] 
12. Hiruma, K.; Gerlach, N.; Sacristán, S.; Nakano, R.T.; Hacquard, S.; Kracher, B.; Neumann, U.; Ramírez, D.; Bucher, M.; Connell, R.J.O.; et al. Root endophyte colletotrichumtofieldiae confers plant fitness benefits that are phosphate status dependent. Cell 2016, 165, 464-474. [CrossRef] [PubMed]

13. Ali, B.; Sabri, A.N.; Ljung, K.; Hasnain, S. Auxin production by plant associated bacteria: Impact on endogenous IAA content and growth of Triticum aestivum L. Lett. Appl. Microbiol. 2010, 48, 542-547. [CrossRef] [PubMed]

14. Olivera, T.; Hussain, M.; Heuer, H. Plants and associated soil microbiota cooperatively suppress plant-parasitic nematodes. Front. Microbiol. 2020, 11, 313.

15. Hussain, M.; Hamid, M.I.; Tian, J.Q.; Hu, J.Y.; Zhang, X.L.; Chen, J.S.; Xiang, M.C.; Liu, X.Z. Bacterial community assemblages in the rhizosphere soil, root endosphere and cyst of soybean cyst nematode-suppressive soil challenged with nematodes. FEMS Microbiol. Ecol. 2018, 94, fiy142. [CrossRef]

16. Hamid, M.I.; Hussain, M.; Wu, Y.P.; Zhang, X.L.; Xiang, M.C.; Liu, X.Z. Successive soybean-monoculture cropping assembles rhizosphere microbial communities for the soil suppression of soybean cyst nematode. FEMS Microbiol. Ecol. 2017, 93, fiw222. [CrossRef]

17. Jiang, Y.N.; Wang, W.X.; Xie, Q.J.; Liu, N.; Liu, L.X.; Wang, D.P.; Zhang, X.W.; Yang, C.; Chen, X.Y.; Tang, D.Z.; et al. Plants transfer lipids to sustain colonization by mutualistic mycorrhizal and parasitic fungi. Science 2017, 356, 1172-1175. [CrossRef]

18. Pieterse, C.M.; der Does, D.V.; Zamioudis, C.; Leon-Reyes, A.; van Wees, S. Hormonal modulation of plant immunity. Annu. Rev. Cell Dev. Biol. 2012, 28, 489-521. [CrossRef]

19. Campos, P.; Borie, F.; Cornejo, P.; Lopez-Raez, J.A.; Lopez-Garcia, A.; Seguel, A. Phosphorus acquisition efficiency related to root traits: Is mycorrhizal symbiosis a key factor to wheat and barley cropping? Front. Plant Sci. 2018, 9, 752. [CrossRef]

20. Pei, D.; Lu, X.Z. (Eds.) Walnut Germplasm Resources in China; China Forestry Publishing House: Beijing, China, 2011. (In Chinese)

21. Zhu, Y.F.; Yin, Y.F.; Qu, W.W.; Yang, K.Q. Occurrence and spread of the pathogens on walnut (Juglans regia) in Shandong Province, China. Acta Hortic. 2014, 1050, 347-351. [CrossRef]

22. Zhu, Y.Z.; Liao, W.J.; Zou, D.X.; Wu, Y.J.; Zhou, Y. First report of leaf spot disease on walnut caused by Colletotrichum fioriniae in China. Plant Dis. 2015, 99, 289. [CrossRef] [PubMed]

23. Cairney, J.W.G.; Meharg, A.A. Ericoid mycorrhiza: A partnership that exploits harsh edaphic conditions. Eur. J. Soil Sci. 2003, 54, 735-740. [CrossRef]

24. Bender, S.F.; Wagg, C.; Heijden, V.D. An underground revolution: Biodiversity and soil ecological engineering for agricultural sustainability. Trends Ecol. Evol. 2016, 31, 440-452. [CrossRef] [PubMed]

25. Savci, S. An agricultural pollutant: Chemical fertilizer. Int. J. Environ. Sci. Dev. 2012, 3, 77-79. [CrossRef]

26. Lin, T.X.; Ye, G.P.; Kuzyakov, Y.; Liu, D.Y.; Fan, J.B.; Ding, W.X. Long-term manure application increases soil organic matter and aggregation, and alters microbial community structure and keystone taxa. Soil Biol. Biochem. 2019, 134, 187-196. [CrossRef]

27. Bulgarelli, D.; Garrido-Oter, R.; Münch, P.C.; Weiman, A.; Dröge, J.; Pan, Y.; McHardy, A.C.; Schulze-Lefert, P. Structure and function of the bacterial root microbiota in wild and domesticated barley. Cell Host Microbe. 2015, 17, 392-403. [CrossRef] [PubMed]

28. Edwards, J.; Johnson, C.; Santos-Medellín, C.; Lurie, E.; Podishetty, N.K.; Bhatnagar, S.; Eisen, J.A.; Sundaresan, V. Structure, variation, and assembly of the root-associated microbiomes of rice. Proc. Natl. Acad. Sci. USA 2015, 112, E911-E920. [CrossRef]

29. Peiffer, J.A.; Spor, A.; Koren, O.; Jin, Z.; Tringe, S.G.; Dangl, J.L.; Buckler, E.S.; Ley, R.E. Diversity and heritability of the maize rhizosphere microbiome under field conditions. Proc. Natl. Acad. Sci. USA 2013, 110, 6548-6553. [CrossRef]

30. Turner, T.R.; Ramakrishnan, K.; Walshaw, J.; Heavens, D.; Alston, M.; Swarbreck, D.; Osbourn, A.; Grant, A.; Poole, P.S. Comparative metatranscriptomics reveals kingdom level changes in the rhizosphere microbiome of plants. ISME J. 2013, 7, 2248-2258. [CrossRef]

31. Martínez-García, P.J.; Crepeau, M.W.; Puiu, D.; Gonzalez-Ibeas, D.; Whalen, J.; Stevens, K.A.; Paul, R.; Butterfield, T.S.; Britton, M.T.; Reagan, R.L.; et al. The walnut (Juglans regia) genome sequence reveals diversity in genes coding for the biosynthesis of non-structural polyphenols. Plant J. 2016, 87, 507-532. [CrossRef] 
32. Zhu, T.; Wang, L.; You, F.M.; Rodriguez, J.C.; Deal, K.R.; Chen, L.; Li, J.; Chakraborty, S.; Balan, B.; Jiang, C.Z.; et al. Sequencing a Juglans regia $\times$ J. microcarpa hybrid yields high-quality genome assemblies of parental species. Hortic. Res. 2019, 6, 55. [CrossRef] [PubMed]

33. Zhang, J.P.; Zhang, W.T.; Ji, F.Y.; Qiu, J.; Song, X.B.; Bu, D.C.; Pan, G.; Ma, Q.G.; Chen, J.X.; Huang, R.M.; et al. A high-quality walnut genome assembly reveals extensive gene expression divergences after whole-genome duplication. Plant Biotechnol. J. 2020, 1-3. [CrossRef] [PubMed]

34. Beckers, B.; Beeck, M.O.; Weyens, N.; Boerjan, W.; Vangronsveld, J. Structural variability and niche differentiation in the rhizosphere and endosphere bacterial microbiome of field-grown poplar trees. Microbiome 2017, 5, 25. [CrossRef] [PubMed]

35. Toju, H.; Tanabe, A.S.; Yamamoto, S.; Sato, H. High-coverage ITS primers for the DNA-based identification of ascomycetes and basidiomycetes in environmental samples. PLoS ONE 2012, 7, e40863. [CrossRef]

36. Edgar, R.C. UPARSE: Highly accurate OTU sequences from microbial amplicon reads. Nat. Methods 2013, 10, 996-998. [CrossRef] [PubMed]

37. Grace, J.B. (Ed.) Structural Equation Modeling and Natural Systems; Cambridge University Press: Cambridge, UK; New York, NY, USA, 2006.

38. Xu, Y.X.; Wang, G.G.; Jin, J.; Liu, J.J.; Zhang, Q.Y.; Liu, X.B. Bacterial communities in soybean rhizosphere in response to soil type, soybean genotype, and their growth stage. Soil Biol. Biochem. 2009, 41, 919-925. [CrossRef]

39. Zhang, J.Y.; Liu, Y.X.; Zhang, N.; Hu, B.; Jin, T.; Xu, H.R.; Qin, Y.; Yan, P.X.; Zhang, X.N.; Guo, X.X.; et al. NRT1. $1 \mathrm{~B}$ is associated with root microbiota composition and nitrogen use in field-grown rice. Nat. Biotechnol. 2019, 37, 676-684. [CrossRef]

40. Leifheit, E.F.; Verbruggen, E.; Rillig, M.C. Arbuscular mycorrhizal fungi reduce decomposition of woody plant litter while increasing soil aggregation. Soil Biol. Biochem. 2015, 81, 323-328. [CrossRef]

41. Stringlis, I.A.; Yu, K.; Feussner, K.; de Jonge, R.; Bentum, S.V.; Verk, M.C.V.; Berendsen, R.L.; Bakker, P.A.H.M.; Feussner, I.; Pieterse, C.M.J. MYB72-dependent coumarin exudation shapes root microbiome assembly to promote plant health. Proc. Natl. Acad. Sci. USA 2018, 115, E5213-E5222. [CrossRef]

42. Wang, M.; Tian, J.Q.; Bu, Z.; Lamit, L.J.; Chen, H.; Zhu, Q.; Peng, C. Structural and functional differentiation of the microbial community in the surface and subsurface peat of two minerotrophic fens in China. Plant Soil. 2019, 437, 21-40. [CrossRef]

43. Mendes, R.; Kruijt, M.; Bruijn, I.; Dekkers, E.; Voort, M.; Schneider, J.H.; Piceno, Y.M.; DeSantis, T.Z.; Andersen, G.L.; Bakker, P.A.H.M.; et al. Deciphering the rhizosphere microbiome for disease-suppressive bacteria. Science 2011, 332, 1097-1100. [CrossRef] [PubMed]

44. Egamberdieva, D.; Kamilova, F.; Validov, S. High incidence of plant growth-stimulating bacteria associated with the rhizosphere of wheat grown on salinated soil in Uzbekistan. Environ. Microbiol. 2008, 10, 1-9. [CrossRef] [PubMed]

45. Hussain, M.; Hamid, M.I.; Wang, N.N.; Bin, L.; Xiang, M.C.; Liu, X.Z. The transcription factor SKN7 regulates conidiation, thermotolerance, apoptotic-like cell death and parasitism in the nematode endoparasitic fungus Hirsutellaminnesotensis. Sci. Rep. 2016, 6, 1-12. [CrossRef] [PubMed]

46. Mwaheb, M.A.; Hussain, M.; Tian, J.Q.; Zhang, X.L.; Hamid, M.I.; El-Kassim, N.A.; Liu, X.Z. Synergetic suppression of soybean cyst nematodes by chitosan and Hirsutellaminnesotensis via the assembly of the soybean rhizosphere microbial communities. Biol. Control. 2017, 115, 85-94. [CrossRef]

47. Sasse, J.; Martinoia, E.; Northen, T. Feed your friends: Do plant exudates shape the root microbiome? Trends Plant Sci. 2018, 23, 25-41. [CrossRef] [PubMed]

48. Zhalnina, K.; Louie, K.; Hao, Z.; Mansoori, N.; Rocha, U.N.D.; Shi, J.S.; Cho, H.J.; Karaoz, U.; Loqué, D.; Bowen, B.P. Dynamic root exudate chemistry and microbial substrate preferences drive patterns in rhizosphere microbial community assembly. Nat. Microbiol. 2018, 3, 470-480. [CrossRef]

49. Zhou, Z.H.; Wang, C.K.; Zheng, M.H.; Jiang, L.F.; Luo, Y.Q. Patterns and mechanisms of responses by soil microbial communities to nitrogen addition. Soil Biol. Biochem. 2017, 115, 433-441. [CrossRef]

50. Leff, J.W.; Jones, S.E.; Prober, S.M.; Barberán, A.; Borer, E.T.; Firn, J.L.; Harpole, W.S.; Hobbie, S.E.; Hofmockel, K.S.; Knops, J.M.H.; et al. Consistent responses of soil microbial communities to elevated nutrient inputs in grasslands across the globe. Proc. Natl. Acad. Sci. USA 2015, 112, 10967-10972. [CrossRef] 
51. Finkel, O.M.; Castrillo, G.; Paredes, S.H.; González, I.S.; Dangl, J.L. Understanding and exploiting plant beneficial microbes. Curr. Opin. Plant Biol. 2017, 38, 155-163. [CrossRef]

52. Dai, Z.; Su, W.; Chen, H.; Barberan, A.; Zhao, H.; Yu, M.; Yu, L.; Brookes, P.C.; Schadt, C.W.; Chang, S.X.; et al. Long-term nitrogen fertilization decreases bacterial diversity and favors the growth of Actinobacteria and Proteobacteria in agro-ecosystems across the globe. Glob. Chang. Biol. 2018, 24, 3452-3461. [CrossRef]

53. Zhao, Q.; Zeng, D.H. Nitrogen addition effects on tree growth and soil properties mediated by soil phosphorus availability and tree species identity. For. Ecol. Manag. 2019, 449, 117478. [CrossRef]

54. Matsuyama, N.; Saigusa, M.; Sakaiya, E.; Tamakawa, K.; Oyamada, Z.; Kudo, K. Acidification and soil productivity of allophanicandosols affected by heavy application of fertilizers. J. Soil Sci. Plant Nut. 2005, 51, 117-123. [CrossRef]

55. Guo, J.H.; Liu, X.J.; Zhang, Y.; Shen, J.L.; Han, W.X.; Zhang, W.F.; Christie, P.; Goulding, K.W.; Vitousek, P.M.; Zhang, F.S. Significant acidification in major Chinese croplands. Science 2010, 327, 1008-1010. [CrossRef] [PubMed]

56. Morrien, E.; Hannula, S.E.; Snoek, L.B.; Helmsing, N.R.; Zweers, A.J.; de Hollander, M.; Soto, R.L.; Bouffaud, M.L.; Buée, M.; Dimmers, W.J.; et al. Soil networks become more connected and take up more carbon as nature restoration progresses. Nat. Commun. 2017, 8, 143-149. [CrossRef] [PubMed]

57. Castro, H.F.; Classen, A.T.; Austin, E.E.; Norby, R.J.; Schadt, C.W. Soil microbial community responses to multiple experimental climate change drivers. Appl. Environ. Microbiol. 2010, 76, 999-1007. [CrossRef]

58. Gottel, N.R.; Castro, H.F.; Kerley, M.; Yang, Z.; Pelletier, D.A.; Podar, M.; Karpinets, T.V.; Uberbacher, E.; Tuskan, G.A.; Vilgalys, R.; et al. Distinct microbial communities within the endosphere and rhizosphere of Populusdeltoides roots across contrasting soil types distinct. Appl. Environ. Microbiol. 2011, 77, 5934-5944. [CrossRef]

59. Lücker, S.; Wagner, M.; Maixner, F.; Pelletier, E.; Koch, H.; Vacherie, B.; Rattei, T.; Damsté, J.S.S.; Spieck, E.; Paslier, D.L.; et al. A Nitrospira metagenome illuminates the physiology and evolution of globally important nitrite-oxidizing bacteria. Proc. Natl. Acad. Sci. USA 2010, 107, 13479-13484. [CrossRef]

60. Zhang, X.X.; Zhang, R.J.; Gao, J.S.; Wang, X.C.; Fan, F.L.; Ma, X.T.; Yin, H.Q.; Zhang, C.W.; Feng, K.; Deng, Y. Thirty-one years of rice-rice-green manure rotations shape the rhizosphere microbial community and enrich beneficial bacteria. Soil Biol. Biochem. 2017, 104, 208-217. [CrossRef]

61. Rawat, S.R.; Männistö, M.K.; Bromberg, Y.; Häggblom, M.M. Comparative genomic and physiological analysis provides insights into the role of Acidobacteria in organic carbon utilization in Arctic tundra soils. FEMS Microbiol. Ecol. 2012, 82, 341-355. [CrossRef]

62. Wang, A.J.; Quan, C.S.; Wang, J.H.; Fan, K.D. Purification and antifungal characterization of a diketopiperazine from Burkholderiacepacia CF-66. China Biotechnol. 2009, 29, 43-48. (In Chinese)

63. Zhou, J.; Guan, D.W.; Zhou, B.K.; Zhao, B.S.; Ma, M.C.; Qin, J.; Jiang, X.; Chen, S.F.; Cao, F.M.; Shen, D.L.; et al. Influence of 34-years of fertilization on bacterial communities in an intensively cultivated black soil in northeast China. Soil Biol. Biochem. 2015, 90, 42-51. [CrossRef]

64. Matsushita, Y.; Egami, K.; Sawada, A.; Saito, M.; Sano, T.; Tsushima, S.; Yoshida, S. Analyses of soil bacterial community diversity in naturally and conventionally farmed apple orchards using 16S rRNA gene sequencing. Appl. Soil Ecol. 2019, 141, 26-29. [CrossRef]

65. Peng, X.J.; Chen, H.; Zhang, X.K.; Yan, X.Q.; Liu, M.; Fu, X.J.; Zhao, G.F.; Yao, P.; Wang, L.L.; Dai, H.; et al. A chromosome-scale genome assembly of paper mulberry (Broussonetiapapyrifera) provides new insights into its forage and papermaking usage. Mol. Plant 2019, 5, 661-677. [CrossRef] [PubMed]

66. Bulgarelli, D.; Schlaeppi, K.; Spaepen, S.; Themaat, E.V.L.; Schulze-Lefert, P. Structure and functions of the bacterial microbiota of plants. Annu. Rev. Plant Biol. 2013, 64, 807-838. [CrossRef] [PubMed]

67. Alibrandi, P.; Cardinale, M.; Rahman, M.D.M.; Strati, F.; Ciná, P.; de Viana, M.L.; Giamminola, E.M.; Gallo, G.; Schnell, S.; de Filippo, C.; et al. The seed endosphere of Anadenanthera colubrina is inhabited by a complex microbiota, including Methylobacterium spp. and Staphylococcus spp. with potential plant-growth promoting activities. Plant Soil. 2018, 422, 81-99. [CrossRef]

68. Jurkevitch, E.; Minz, D.; Ramati, B.; Barel, G. Prey range characterization, ribotyping, and diversity of soil and rhizosphere Bdellovibrio spp. isolated on phytopathogenic bacteria. Appl. Environ. Microb. 2000, 66, 2365-2371. [CrossRef] [PubMed] 
69. Xu, J.; Zhang, Y.Z.; Zhang, P.F.; Trivedi, P.; Riera, N.; Wang, Y.Y.; Liu, X.; Fan, G.Y.; Tang, J.L.; Coletta-Filho, H.D.; et al. The structure and function of the global citrus rhizosphere microbiome. Nat. Commun. 2018, 9, 4894. [CrossRef]

70. Harman, G.E.; Howell, C.R.; Viterbo, A.; Chet, I.; Lorito, M. Trichoderma species-opportunistic, avirulent plant symbionts. Nat. Rev. Microbiol. 2004, 2, 43-56. [CrossRef]

71. Hu, J.Y.; Hussain, M.; Zhang, X.L.; Tian, J.Q.; Liu, X.Z.; Duan, Y.X.; Xiang, M.C. Abundant and diverse fungal microbiota inhabit the white females and brown cysts of the cereal cyst nematode. Appl. Soil Ecol. 2020, 147, 103372. [CrossRef]

72. Yang, B.; Wang, X.M.; Ma, H.Y.; Jia, Y.; Li, X.; Dai, C.C. Effects of the fungal endophyte Phomopsis liquidambari on nitrogen uptake and metabolism in rice. Plant Growth Regul. 2014, 73, 165-179. [CrossRef]

73. Kong, W.L.; Li, P.S.; Wu, X.Q.; Wu, T.Y.; Sun, X.R. Forest tree associated bacterial diffusible and volatile organic compounds against various phytopathogenic fungi. Microorganisms 2020, 8, 590. [CrossRef] [PubMed]

74. Bossio, D.A.; Girvan, M.S.; Verchot, L.; Bullimore, J.; Borelli, T.; Albrecht, A.; Scow, K.M.; Ball, A.S.; Pretty, J.N.; Osborn, A.M. Soil microbial community response to land use change in an agricultural landscape of western Kenya. Microb. Ecol. 2005, 49, 50-62. [CrossRef] [PubMed]

75. Xu, S.Q.; Tian, L.; Chang, C.L.; Li, X.J.; Tian, C.J. Cultivated rice rhizomicrobiome is more sensitive to environmental shifts than that of wild rice in natural environments. Appl. Soil Ecol. 2019, 140, 68-77. [CrossRef]

76. Hamonts, K.; Trivedi, P.; Garg, A.; Janitz, C.; Grinyer, J.; Holford, P.; Botha, F.C.; Anderson, I.C.; Singh, B.K. Field study reveals core plant microbiota and relative importance of their drivers. Environ. Microbiol. 2018, 20, 124-140. [CrossRef]

77. Lemanceau, P.; Blouin, M.; Muller, D.; Moënne-Loccoz, Y. Let the core microbiota be functional. Trends Plant Sci. 2017, 22, 583-595. [CrossRef]

78. Yarwood, S.A. The role of wetland microorganisms in plant-litter decomposition and soil organic matter formation: A critical. FEMS Microbiol. Ecol. 2018, 94, 175. [CrossRef]

79. Berendsen, R.L.; Pieterse, C.M.J.; Bakker, P.A.H.M. The rhizosphere microbiome and plant health. Trends Plant Sci. 2012, 17, 478-486. [CrossRef]

80. Tedersoo, L.; Bahram, M.; Polme, S.; Koljalg, U.; Yorou, N.S.; Wijesundera, R.; Villarreal, R.L.; Vasco-Palacios, A.M.; Thu, P.Q.; Suija, A.; et al. Fungal biogeography. Global diversity and geography of soil fungi. Science 2014, 346, 1256688. [CrossRef]

81. Schjoerring, J.K.; Cakmak, I.; White, P.J. Plant nutrition and soil fertility: Synergies for acquiring global green growth and sustainable development. Plant Soil. 2019, 434, 1-6. [CrossRef]

82. Zhao, Z.B.; He, J.Z.; Geisen, S.; Han, L.L.; Wang, J.T.; Shen, J.P.; Wei, W.X.; Fang, Y.T.; Li, P.P.; Zhang, L.M. Protist communities are more sensitive to nitrogen fertilization than other microorganisms in diverse agricultural soils. Microbiome 2019, 7, 33. [CrossRef]

83. Sun, R.B.; Zhang, X.X.; Guo, X.S.; Wang, D.Z.; Chu, H.Y. Bacterial diversity in soils subjected to long-term chemical fertilization can be more stably maintained with the addition of livestock manure than wheat straw. Soil Biol. Biochem. 2015, 88, 9-18. [CrossRef]

84. Zhou, J.; Jiang, X.; Zhou, B.K.; Zhao, B.S.; Ma, M.C.; Guan, D.W.; Li, J.; Chen, S.F.; Cao, F.M.; Shen, D.L.; et al. Thirty-four years of nitrogen fertilization decreases fungal diversity and alters fungal community composition in black soil in northeast China. Soil Biol. Biochem. 2016, 95, 135-143. [CrossRef]

85. Shen, F.F.; Wu, J.P.; Fan, H.B.; Liu, W.F.; Guo, X.M.; Duan, H.L.; Hu, L.; Lei, X.M.; Wei, X.H. Soil N/P and C/P ratio regulate the responses of soil microbial community composition and enzyme activities in a long-term nitrogen loaded Chinese fir forest. Plant Soil. 2019, 436, 91-107. [CrossRef]

86. Boilard, G.; Bradley, R.L.; Paterson, E.; Sim, A.; Brown, L.K.; George, T.S.; Bainard, L.; Carubba, A. Interaction between root hairs and soil phosphorus on rhizosphere priming of soil organic matter. Soil Biol. Biochem. 2019, 135, 264-266. [CrossRef]

87. Tahovskáet, K.; Choma, M.; Kaštovskáa, E.; Oulehle, F.; Bárta, J.; Šantrůčková, H.; Moldan, F. Positive response of soil microbes to long-term nitrogen input in spruce forest: Results from Gårdsjön whole-catchment N-addition experiment. Soil Biol. Biochem. 2020, 143, 107732. [CrossRef] 
88. Mendes, L.W.; Kuramae, E.E.; Navarrete, A.A.; Van, V.J.; Tsai, S.M. Taxonomical and functional microbial community selection in soybean rhizosphere. ISME J. 2014, 8, 1577. [CrossRef]

89. Müller, D.B.; Vogel, C.; Bai, Y.; Vorholt, J.A. The plant microbiota: Systems-level insights and perspectives. Annu. Rev. Genet. 2016, 50, 211-234. [CrossRef]

(C) 2020 by the authors. Licensee MDPI, Basel, Switzerland. This article is an open access article distributed under the terms and conditions of the Creative Commons Attribution (CC BY) license (http://creativecommons.org/licenses/by/4.0/). 